\title{
16. DISTRIBUTION OF CALCAREOUS DINOFLAGELLATES IN CENOZOIC SEDIMENTS OF SITE 366, EASTERN NORTH ATLANTIC
}

\author{
Dieter Fütterer, Geologisch-Paläontologisches Institut der Universität Kiel, \\ Olshausenstr. 40/60, D-23 Kiel, Germany FRG
}

\begin{abstract}
Paleocene to Pleistocene calcareous dinoflagellates in samples from DSDP Leg 41, Site 366 on the Sierra Leone Rise in the eastern North Atlantic are described using scanning electron microscopy (SEM). Two new species of Thoracosphaera were encountered. One species is rejected representing a diagenetically altered modification. Several species are described and illustrated for the first time by SEM examinations.

The stratigraphic distribution of individual species described here shows restricted ranges, although a few long-ranging species are present. More complete investigation of regionally widespread material may result in using calcareous dinoflagellates as valuable index fossils.
\end{abstract}

\section{INTRODUCTION}

Until recently not much information has been published about calcareous dinoflagellates. This group was first mentioned by Deflandre (1947) who described Calciodinellum operosum as the type genus of the family Calciodinellidae. Descriptions of several more monospecific genera followed (Deflandre, 1948).

No progress was made until the work of Wall and Dale (1968), who isolated these organisms from modern marine sediments and studied them in incubation experiments. They described several new morphotypes and stressed that modern calcareous dinoflagellates are resting cysts in the life cycle and not thecae and are identical in this respect with other fossil dinoflagellates and hystrichospheres. Until quite recently the only additional papers on dinoflagellates were Wall and Dale $(1966,1967)$ and Wall et al. $(1970,1973)$.

Futterer (1976) discusses the taxonomic position of the Thoracosphaeroideae resulting in the statement that all Thoracosphaeroideae are calcareous dinoflagellate cysts and are closely related to Calciodinellum operosum and related genera. Hitherto the systematic position of the Thoracosphaeroideae was somewhat confused. The general agreement was to include this genus as a part of the calcareous nannoplankton. Kamptner (1927) classified them within the coccolithophorids although he himself had strong suspicions. But in spite of all suspicions, this group was still classified as a proper family within the coccolithophorids or at least was placed as a group "incertae sedis" into their close connection (Reinhardt, 1972). However, repeated demands for precise revision were made (Bramlette and Martini, 1964; Cohen, 1965; Perch-Nielsen, 1971).

The confusions have been clarified by placing these forms in the subfamily Thoracosphaeroideae, which probably belongs to the order Peridiniales of the Dinophyceae and consists of several genera listed in
Table 1. Additionally, there are some modern dinoflagellate species which produce calcareous cysts mentioned by Wall and Dale (1968) and Wall et al. (1970). Taxonomic problems of relating modern species to fossil species are discussed by Wall and Dale (1968).

Thus, the occurrences of calcareous dinoflagellates have been known for a long time, but they have been classified in different taxonomic units. However, compared with other groups of nannofossils or microfossils, very little attention has been paid to their biostratigraphy. This is caused by patchy or incidental examination without systematic biostratigraphic investigations. Undoubtedly the small size of the microfossils and the difficulties of examination with light microscopy also play an important role. Systematic descriptions of the species are highly confused because of a limited depth of focus and resolution of light microscopy.

Twenty species are mentioned in the published record (Perch-Nielsen, 1971). It is certain that at least half of all the described species are invalid and represent synonyms of other species. A modern systematic revision using SEM-methodology has been lacking, although the first steps have been taken (Fütterer, 1976).

TABLE 1

Fossil Genera of Calcareous Dinoflagellates (all genera besides Thoracosphaera are monospecific)

\begin{tabular}{lll}
\hline \multicolumn{1}{c}{ Genus } & \multicolumn{1}{c}{ Type Species } & \multicolumn{1}{c}{ Age/Range } \\
\hline Thoracosphaera Kamptner, 1927 & T. heimi (L.) Kamptner & Cretaceous-Recent \\
Calciodinellum Deflandre, 1947 & C. operosum Deflandre & Miocene-Recent \\
Calciogranellum Deflandre, 1948 & C. limbatum Deflandre & Miocene \\
Calcigonellum Deflandre, 1948 & C. infula Deflandre & Miocene \\
Calcipterellum Deflandre, 1948 & C. colomi Deflandre & Miocene \\
Biechelerella Deflandre, 1948 & B. jurassica Deflandre & Oxfordium \\
Bicarinellum Deflandre, 1948 & B. castaninum Deflandre & Eocene \\
incertae sedis & & \\
Calcisphaerellum Deflandre, 1948 & C. flosculus Deflandre & Oxfordium \\
Calcicarpinum Deflandre, 1948 & C. tetraedrum Deflandre & Eocene \\
\hline
\end{tabular}


Diagenetic effects cause additional confusion. It has been quite evident for several years that diagenesis influences nannofossil and microfossil communities (Adelseck et al., 1973; Berger, 1968; McIntyre and McIntyre, 1971). A fossil of given structure and morphology may, with diagenetic effects, change its characteristics to become a "new diagenetic" species.

Consequently, a continuous section from the Paleocene to Pleistocene was examined by scanning electron microscopy for biostratigraphic distribution of calcareous dinoflagellates, especially of the genus Thoracosphaera. This paper presents a major revision of thoracosphaerid species, particularly by taking into consideration the effects of diagenesis which modified existing species or even created "diagenetic" species.

\section{MATERIAL}

The present study is based on core material recovered during DSDP Leg 41 on Sierra Leone Rise at Site 366 (Figure 1). The 850-meter-thick sedimentary sequence at this site was continuously cored, thus providing a nearly complete section spanning from early Paleocene to Pleistocene.

One sample from each section in the Neogene interval was selected for examination, whereas in deeper cores only the core-catcher sample was examined (Table 3). The same samples were used by

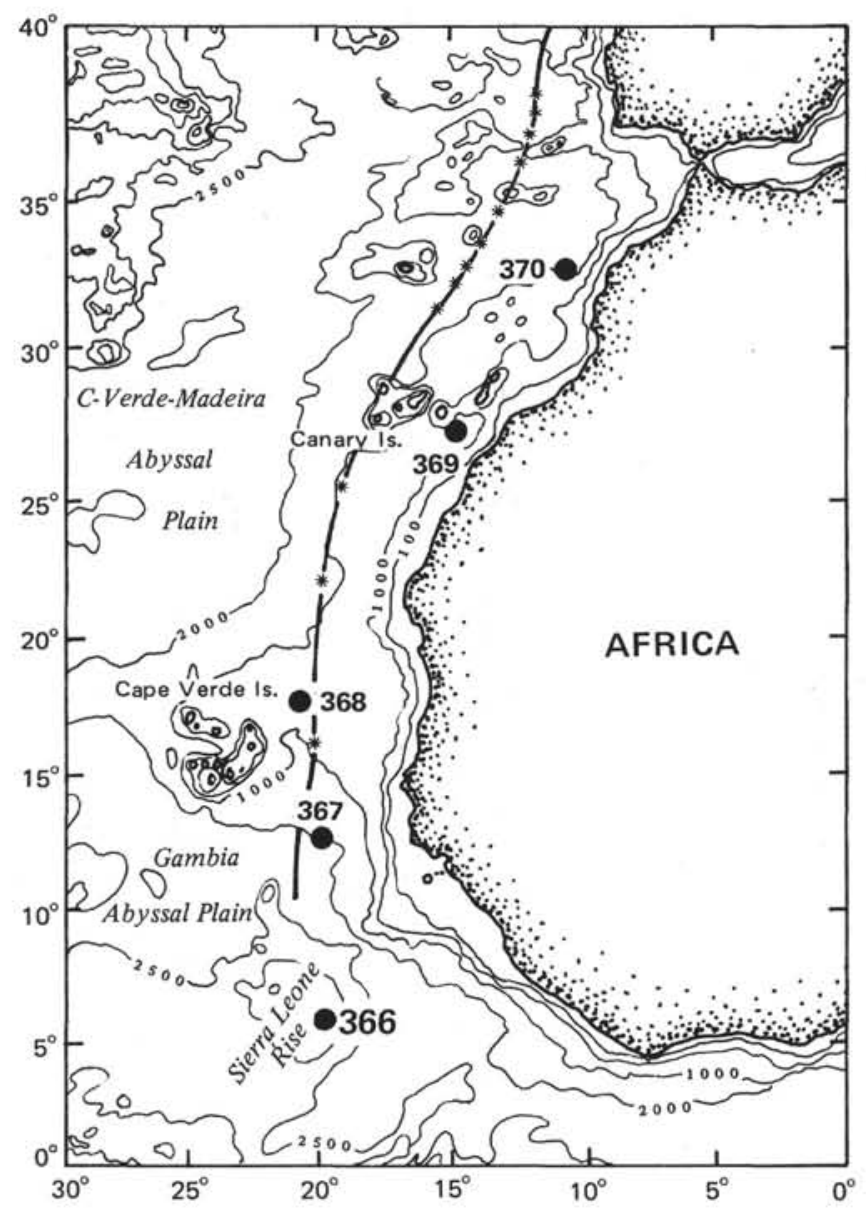

Figure 1. Index map showing the bathymetry of the Sierra Leone Rise and location of Site 366.
Pflaumann and Krasheninnikov (this volume) for foraminiferal stratigraphy, Samtleben (this volume) for Neogene coccolith communities, Futterer (this volume) for Neogene silt fraction analysis, and Diester-Haass (this volume) for coarse grain analyses.

The isolated position of Site 366 on the Sierra Leone Rise has resulted in pelagic sedimentation of mainly biogenic origin. The sedimentary succession consists of nanno or marly ooze grading down into limestone and marlstone. No large hiatuses occur, and all biostratigraphic zones have been sampled. Because of this, the continuous coring, and the simultaneous occurrence of different microfossil and nannofossil groups, this drill site is ideal for testing the biostratigraphic succession and usefulness of a new group. Fossil preservation is quite good, although distinct grades of diagenetic modification of fossil preservation are observed in late Miocene at 110 meters and in middle Eocene at 500 to 540 meters depth.

\section{METHODS OF STUDY}

All samples were washed through $40 \mu \mathrm{m}$ and $63 \mu \mathrm{m}$ mesh sieves. The Pliocene/Pleistocene samples were treated with $\mathrm{H}_{2} \mathrm{O}_{2}$ prior to washing to promote rapid disaggregation. The $>40 \mu \mathrm{m}$ fractions were tested for thoracosphaerids by using a light microscope. The material of $<40 \mu \mathrm{m}$ size was fractionated by sedimentation analyses using a modified Atterberg method. The 6 to $40 \mu \mathrm{m}$ fractions were mounted on SEM stubs, using photographic paper as adhesive. Subsequently, the samples were coated twice with carbon and goldpalladium for SEM examination. The specimens on the stub were counted directly from the SEM screen by examining a set number of sections across the SEM stub. This gives a semiquantitative distribution for each species. The relative abundance of each species recorded in Table 3 refers to frequencies counted on one section across the SEM stub and is given as follows: $\mathrm{A}$, abundant (more than 25 specimens); $\mathrm{C}$, common ( 15 to 25 specimens); F, few ( 5 to 15 specimens); $R$, rare ( 1 to 5 specimens) and $r$, very rare (less than one specimen).

Over 1400 SEM photographs were made for systematic taxonomy. Light optical examinations were also carried out for comparison of SEM results and descriptions of species taken from the literature.

\section{Preservation of Fossil Calcareous Dinoflagellates}

Preservation of calcareous dinoflagellates was estimated by comparison with discoasters and coccoliths. The degree of secondary calcite overgrowth on the nannofossils, especially when using discoasters as a measure of diagenetic influence, generally increases with depth of burial. The uppermost 80 meters show excellent fossil preservation with no visible overgrowth on discoasters and coccoliths although some dissolution was seen on delicate forms and structures. Weak overgrowths occur in Sample 366A-10, CC/11, CC which form delicate ridges on discoaster rays, whereas somewhat deeper in the section (Sample 366A-12, CC), extensive secondary calcite overgrowth occurs. Overgrowth and dissolution become more extensive 
deeper in the section. Miocene and Eocene siliceous units rich in biogenic opal have poor preservation.

In comparison with the discoasters, calcareous dinoflagellates show quite complex diagenetic effects. A species-specific behavior similar to that in coccoliths is found among the calcareous dinoflagellates. One group is very susceptible to diagenetic overgrowth whereas the other shows delicate skeletal structures which lack any overgrowth even in strongly diagenetically altered sections.

The most abundant representative of the former group is Thoracosphaera heimi, the type species of its genus. Fresh, modern specimens of this species are extremely fragile, often collapsing during preparation. After burial the test soon becomes more solid, probably by recrystallization of its skeletal elements. The next step of diagenetic alteration is similar to the effects seen in discoasters (Sample 366A-8, CC). The pores of the skeletal elements are closed by secondary calcite whereas the primary crystallite ornamentation of the distal surface is smoothed (Plate 1, Figures 3,6). These processes are further developed with continuing diagenesis and the resulting specimens show sturdy, distal and proximal, weakly domed skeletal elements (Plate 1, Figure 7). Weak molds exhibit remnants of the primary pore structure in the intermediate stage (Plate 1 , Figures 8,11$)$. In the final stage, the distal surface is composed of smooth and rounded skeletal elements (Plate 1, Figures 9, 12) whereas the proximal surface is composed of euhedral crystal faces (Plate 1, Figure 10).

Specimens of this type have been described often in the literature and have been always classified as Thoracosphaera imperforata which is a younger synonym for $T$. heimi and has to be rejected.

Other species highly susceptible to diagenesis are $T$. granifera (Plate 2, Figures 11, 12), T. deflandrei (Plate 4, Figures 1-6) and T. saxea (Plate 4, Figures 7-12). The latter two species are only known as altered and recrystallized forms. Sediments less influenced by diagenesis might reveal the original state of these species.

The other group, lacking any overgrowth even in samples strongly altered by diagenesis, is comprised mostly of $T$. albatrosiana, T. tesserula, Thoracosphaera sp. 5, and Calciodinellum operosum. See Table 2 for a complete compilation.

\section{Taxonomic Criteria Used In Fossil Calcareous Dinoflagellates}

Until now, the essential criterion of distinction on a generic level has been the presence or absence of ridges and their distribution on the test. This reflects tabulation of dinoflagellates. Shape and outline of the test have been given only minor significance. This method is highly unsatisfactory because it results in several monospecific genera (Deflandre, 1948) and only one genus, Thoracosphaera, which comprises all types without ridges.

Among modern calcareous dinoflagellates whose thecae and corresponding cysts are known, cyst types with ridges, or carinae, and spinose types are present. All these species belong to different genera, but form a closely related group (Wall and Dale, 1968). Our
TABLE 2

Susceptibility of Calcareous Dinoflagellates to Diagenetic Alterations

\begin{tabular}{|c|c|c|c|}
\hline \multirow[b]{2}{*}{ Species } & \multicolumn{3}{|c|}{ Suscep tibility } \\
\hline & High & Medium & Low \\
\hline Thoracosphaera heimi & $\mathrm{X}$ & & \\
\hline T. saxea & $\mathrm{X}$ & & \\
\hline T. deflandrei & $X$ & & \\
\hline T. granifera & $\mathrm{X}$ & & \\
\hline T. tesserula & & & $\mathrm{X}$ \\
\hline T. tuberosa & & $\mathrm{X}$ ? & \\
\hline T. operaculata & & $\mathrm{X}$ ? & \\
\hline T. albatrosiana & & & $\mathrm{X}$ \\
\hline T. sp. 1 & & & $\mathrm{X}$ ? \\
\hline T. sp. 2 & $\mathrm{X}$ & & \\
\hline T. sp. 3 & & & $\mathrm{X}$ \\
\hline$T$. sp. 4 & & $\mathrm{X}$ ? & \\
\hline T. sp. 5 & & & $\mathrm{X}$ \\
\hline T. sp. 6 & & $\mathrm{X}$ ? & \\
\hline Calciodinellum operosum & & & $\mathrm{X}$ \\
\hline Peridinium $\mathrm{cf}$. $P$. trochoideum & & & $\mathrm{X}$ ? \\
\hline
\end{tabular}

present knowledge, however, is not sufficient to discuss this problem in detail or even to create new classifications which include fossil and modern forms.

The main criteria within the genus Thoracosphaera are (1) width, shape, and outline of the archaeopyle; (2) skeletal ultrastructure showing size, shape, and arrangement of skeletal elements; and (3) test size. The last item is used with some reservations. Presence or absence of an operculum depends on the mode of test construction and especially on preservation.

The type of the archaeopyle is easily discernible, although this feature is often obscured by damage to the test. The skeletal ultrastructure, for a long time used as taxonomic criterion (size and shape of elements), has led to an enormous confusion in the taxonomy of the thoracosphaerids. Problems were caused by the insufficient resolution and depth of focus of light microscopy. The details of the ultrastructure are clearly visible and easily distinguished by SEM observations. Finally, confusion has resulted when a diagenetic influence becomes important, as in the case of T. heimi or "T. imperforata."

\section{Trends in Calcareous Dinoflagellates}

The examined samples range stratigraphically from Paleocene to Pleistocene, and include 10 species and 6 forms in open nomenclature of calcareous dinoflagellates (Table 3 ). Although it is too early to give definite ranges of species because only one section was sampled continuously, the data indicate limited stratigraphic ranges for most of the species. Only one species, $T$. heimi, ranges from Paleocene to Pleistocene and only one other species, $T$. saxea, is considered to be long ranging (Figure 2).

There are still discrepancies in published ranges of species. For example, $T$. deflandrei is described in the literature from lower Cretaceous to Eocene (Stradner, 1961). It is present only from the early to the middle Miocene on the Sierra Leone Rise. T. saxea is present from the Paleocene to the early Miocene at Site 366, 
D. FÜTTERER

TABLE 3

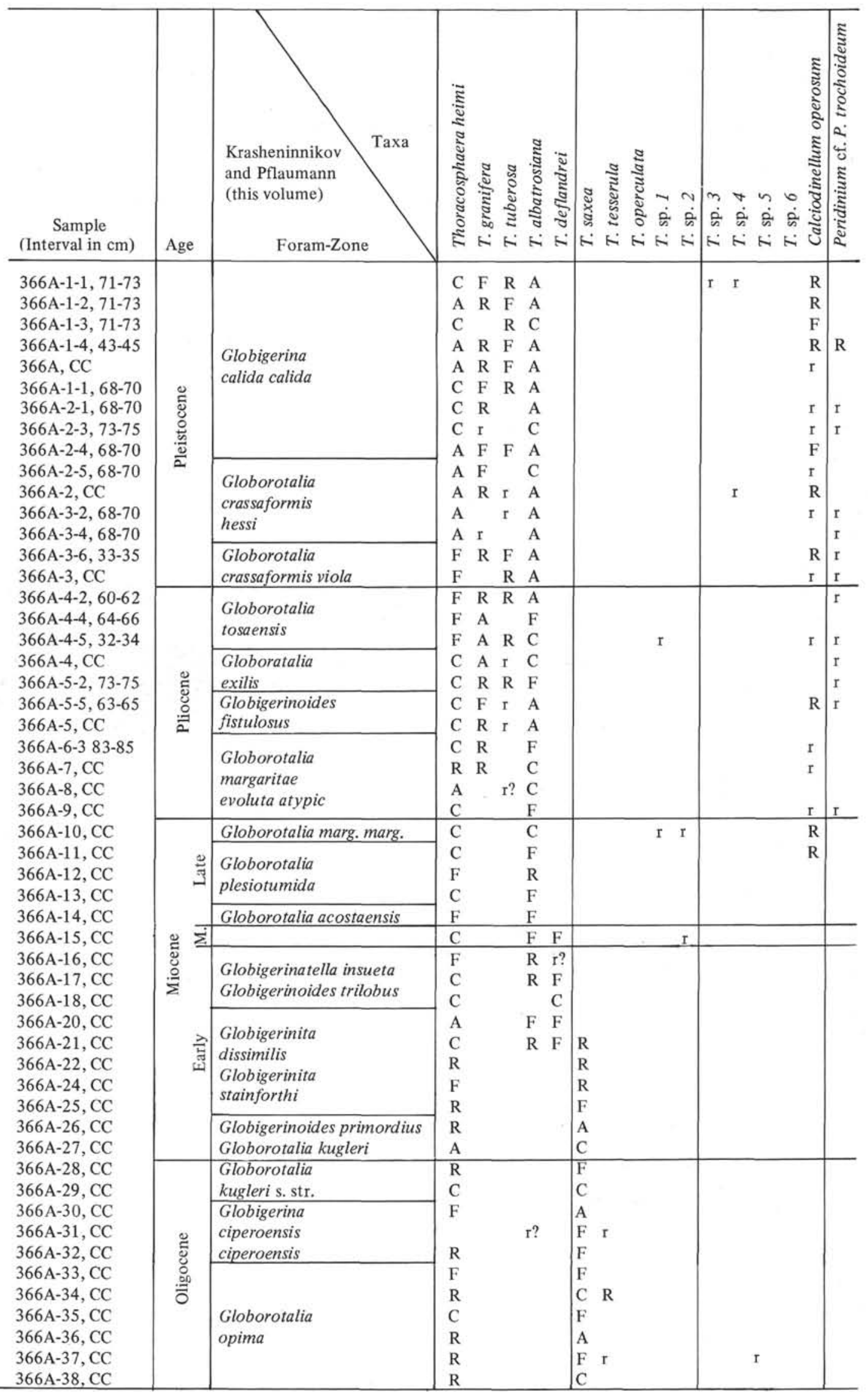


TABLE 3 - Continued

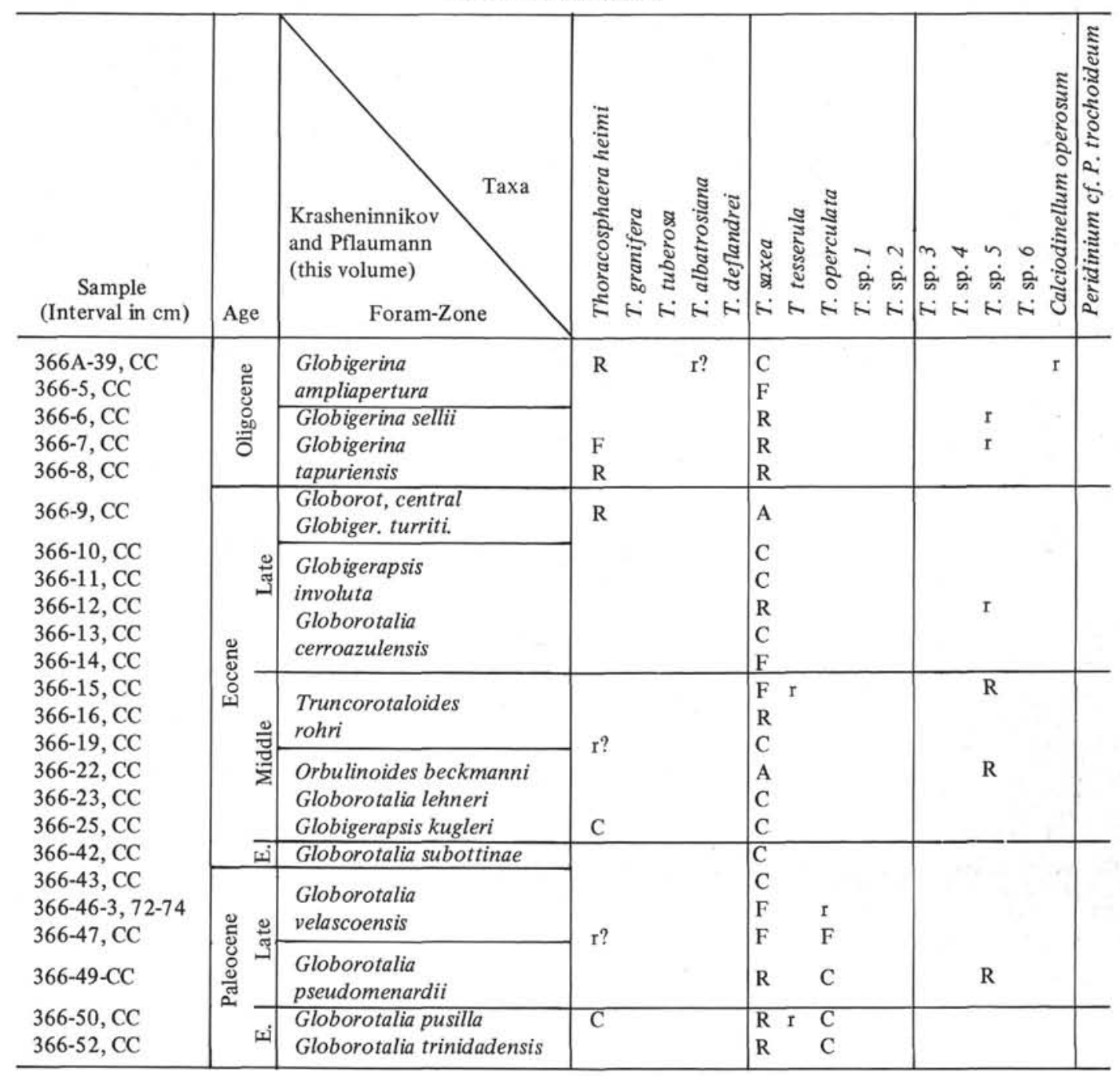

whereas in the literature it is described from Holocene sediments (Cohen, 1964) as well as from Pliocene to Holocene sediment cores (Boudreaux and Hay, 1969). In general, however, stratigraphic ranges of most species show excellent agreement with those given in the literature.

The almost constant distribution of the number of species in each stratigraphic unit and the number of specimens within each sample is remarkable, although there is a distinct increase in frequency of specimens during Pliocene and Pleistocene. This may be a result of sample preservation, but an evolutionary trend is not excluded.

From the point of view of evolution, all Paleocene thoracosphaerids have small, circular archaeopyles with or without a preserved operculum ( $T$. heimi, $T$. saxea, T. tesserula, T. operculata). T. albatrosiana occurs during the early Miocene as the first species which shows a large archaeopyle with a zig-zag margin. It is followed in late Miocene by $C$. operosum, by $T$. tuberosa in Pliocene, and by $T$. sp. 3 and 4 during Pleistocene. The large archaeopyle seems to be a new evolutionary feature, as is reflected tabulation by crystallite ridges in C. operosum and the development of spines seen within the modern peridinoid group.
The ultrastructure of the Paleocene $T$. operculata is composed of tiny crystallites arranged in circles around a central pore producing a reticulated test pattern. A similar ultrastructure is found in T. albatrosiana which occurs in the early Miocene. The only difference between the two is the smaller circular archaeopyle of $T$. operculata.

The same situation is seen in Thoracosphaera sp. 5, found from the Paleocene to the Oligocene. It has a small, circular archaeopyle whereas T. tuberosa, found from the Pliocene to Pleistocene, has a large archaeopyle. Both species possess nearly identical ultrastructure.

These features may reflect an evolution of calcareous dinoflagellate tests and archaeopyles.

\section{SYSTEMATIC PALEONTOLOGY}

Subfamily THORACOSPHAEROIDEAE Kamptner, 1928

Genus THORACOSPHAERA Kamptner, 1927

Thoracosphaera heimi (Lohmann) Kamptner, 1920 (Plate 1, Figures 1-12)

*Syracosphaera heimi n. sp. Lohmann, 1920, Arch. Biont., v. 4, p. 117, fig. 29. 


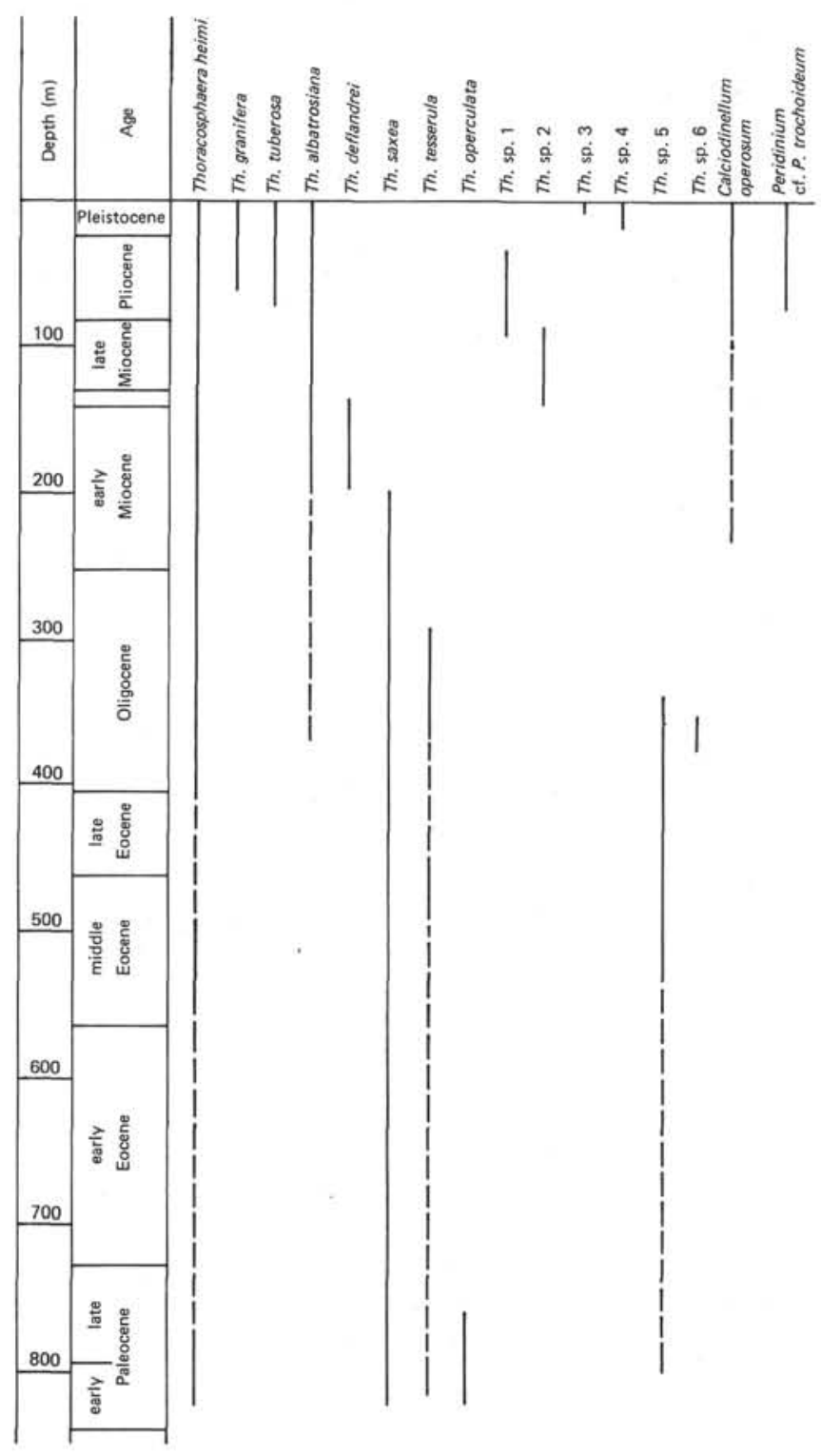

Figure 2. Stratigraphic range chart of calcareous dinoflagellates from Site 366, Sierra Leone Rise.

Thoracosphaera pelagica n. sp. Kamptner, 1927, Arch. Protistenk., v. 58 , p. 180 , fig. 6 .

Thoracosphaera heimi (Lohmann) Kamptner. Kamptner, 1944, Wien. Bot. Z., v. 93, p. 145.

Thoracosphaera imperforata n. sp. Kamptner, 1946, Anz. Akad. Wiss. Wien, Math. Nat. KI., v. 83 , p. 100 , nomen nudum.

Thoracosphaera heimi (Lohmann) Kamptner. Kamptner, 1954, Arch. Protistenk., v. 100, fig. 41, 42.

Thoracosphaera imperforata Kamptner. Kamptner, 1955, Ver. K. Ned. Akad. Wet., Afd. Nat., R.2, v. 50 , p. 37, 66-71, pl. 8 , fig. 98.

Thoracosphaera heimi Kamptner. Stradner, 1961, Erdol-Z., v. 77, p. 84 , fig. 75 .

Thoracosphaera granulosa n.sp. Kamptner, 1963, Ann. Naturhistor. Mus. Wien, v. 66, p. 178, fig. 28.

Thoracosphaera imperforata Kamptner. Kamptner, 1963, Ann. Naturhistor. Mus. Wien, v. 66, p. 179, pl. 5, fig. 29, 31.

Thoracosphaera heimi (Lohmann) Kamptner. Cohen, 1964, Micropaleontology, v. 10, p. 248, pl. 5, fig. 7a-b.

Thoracosphaera heimi (Kamptner, 1927). Cohen, 1965, Leid. Geol. Meded., v. 35 , p. 30 , pl. 5, fig. f.

?Thoracosphaera imperforata Kamptner. Cohen, 1965, Leid. Geol. Meded., v. 35, p. 31, pl. 5, fig. g.
Thoracosphaera heimi (Lohmann) Kamptner. Kamptner, 1967, Ann. Naturhistor. Mus. Wien, v. 71, p. 158, fig. 89-92, 95, 104.

Thoracosphaera corsena n.sp. Kamptner, 1967, Ann Naturhistor. Mus. Wien, v. 71 , p. 157 , fig. $82-85$.

Thoracosphaera heimi (Lohmann) Boudreaux and Hay, 1969, Rev. Esp. Micropal., v. 1, p. 265, pl. 3, fig. 14-19, pl. 4, fig. 1,

Thoracosphaera cf. T. deflandrei Haq and Lipps, 1971, Deep Sea Drilling Proj., Initial Report, v. 8, p. 798, pl. 6.

Thoracosphaera heimii (Lohmann) Kamptner. Edwards, 1973, Deep Sea Drilling Proj., Initial Reports, v. 2I, pl. 3, fig. 4-6.

Thoracosphaera heimi (Lohmann) Kamptner. Müller, 1974, Deep Sea Drilling Proj., Initial Report, v. 25, pl. 16, fig. 6-7, non fig. $8=$ T. albatrosiana.

Thoracosphaera deflandrei Kamptner. Haq and Lohmann, 1975, Woods Hole Oceanogr. Inst., Tech. Rept. WHOI-75-45, pl. 3, fig. 10.

Thoracosphaera heimi (Lohmann) Kamptner. Fütterer, 1976, N. Jb. Geol. Paläont. Abh., v. 151, p.130-132, fig. 19-25.

Description from SEM examinations: The test of $T$. heimi is spherical and 9 to $20 \mu \mathrm{m}$ in diameter. The apical archaeopyle is circular and 3 to $7 \mu \mathrm{m}$ in width comprising up to one-third of the test diameter.

The skeletal elements are quite variable in shape and size and of irregular polygonal outline, forming small platelets 1 to $2.5 \mu \mathrm{m}$ wide and about $1 \mu \mathrm{m}$ thick. The elements show a smooth base interrupted by tiny, pore-like structures, whereas the outer surface shows somewhat blurred euhedral crystallites of variable orientation normally surrounding a central pore. These pores are only ornamental, and do not go directly through the test wall. It may be that the pores branch inside the platelet-like skeletal elements into tiny conduits which open on the proximal test surface in the previously described pore-like structures on the bases of the skeletal elements.

The ultrastructure of the skeletal elements is composed of numerous minute granular crystallites. This may be seen only in broken sections.

Remarks: The most complete description from light optical examinations is found in Kamptner (1927) whereas excellent figures are found in Kamptner (1967).

The above description is valid only for modern or fresh material. This refers to specimens lacking any diagenetic crystallite overgrowth. In contrast to $T$. albatrosiana or $T$. tuberosa, $T$. heimi is very susceptible to diagenetic influences. The ornamental pores become smaller as crystallite overgrowth covers them until they disappear completely. The distal crystallite relief is rapidly compensated by this orientated crystallite overgrowth (Plate 1, Figure 6). This results finally in highly altered and extremely dense specimens. The diagenetically influenced $T$. heimi displays nonperforated skeletal elements or platelets without any pore-like structure on a test showing no size change (Plate 1, Figures 11, 12). Sometimes a small depression on the distal surface forms the only remnant of the former pore structure. The platelets are 1 to $3 \mu \mathrm{m}$ wide and 1 to $2 \mu \mathrm{m}$ thick and show a slight convex curvature on distal and proximal surfaces (Plate 1, Figure 7). The latter often display somewhat euhedral crystal faces (Plate 1, Figure 10).

This description is completely identical even in details to that of Thoracosphaera imperforata given by Kamptner (1955). Therefore, the name $T$. imperforata should be replaced by $T$. heimi.

The logical consequence of the high susceptibility of $T$. heimi to diagenetic alteration is an abnormally large range of variation in skeletal morphology. The size of the skeletal elements also varies considerably as does the test size. The number of skeletal elements composing a definite spherical segment are plotted against test diameter in Figure 3. Modern specimens of T. heimi s.str. (open circles), slightly altered specimens showing typical "heimi features" (filled circles), as well as diagenetically altered specimens showing no pore structures (triangle), occupy almost identical areas of the diagram. Consequently, size and number of skeletal elements, just as the size of the test, are no significant criteria to us to split $T$. heimi into several species. Even the specimens (Plate 1, Figure 4) which at first glance are slightly different from the typical form (filled squares in Figure 3), do not show significant differences other than smaller size and fewer elements.

Some confusion of diagenetically altered $T$. heimi with $T$. deflandrei might be possible. However, the skeletal elements of $T$. heimi are wider than they are thick, whereas in $T$. deflandrei they are thicker or longer than they are wide.

Age and range of species: $T$. heimi is frequent to abundant in the Sierra Leone Rise section in Holocene to Paleocene sediments. This species is the most abundant low latitudes form. 


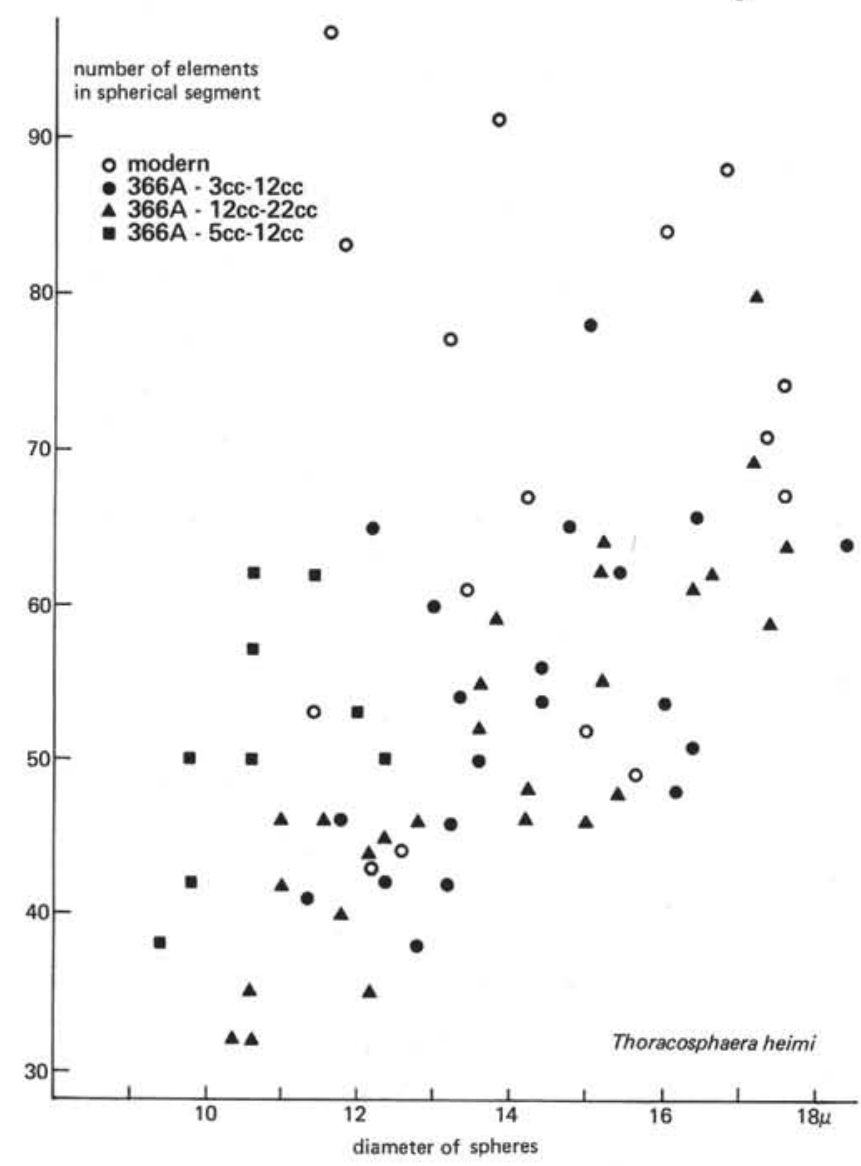

Figure 3. Number of skeletal elements in relation to test size of Thoracosphaera heimi with regard to different stages of preservation.

\section{Thoracosphaera granifera n.sp. \\ (Plate 2, Figures 1-12)}

Description from SEM examinations: The test is quite spherical and 16 to $26 \mu \mathrm{m}$ in diameter with a pronounced maximum in a range from 18 to $20 \mu \mathrm{m}$. The perfectly circular archaeopyle is 5 to $9 \mu \mathrm{m}$ in width and is closed by an operculum of similar dimensions which is sometimes preserved in situ. The test wall is about $1.5 \mu \mathrm{m}$ in thickness and composed of single, granular, tightly packed crystallites of 0.1 to $0.2 \mu \mathrm{m}$ in diameter. These crystallites or granules do not have a specific orientation although a linear arrangement can be observed on the distal test surface. The granule crystallites may laterally blend into each other, producing a delicate porous texture.

Remarks: $T$. granifera is very susceptible to diagenetic alteration. Often an undefined, granular crystallite overgrowth is seen obscuring the primary ultrastructure (Plate 2, Figure 12). Frequent and characteristic segmentation of the granular test surface into irregular, plate-like elements is seen (Plate 2, Figure 11).

A certain distinction from $T$. deflandrei is easily possible by comparison of the skeletal crystallites: $T$. deflandrei has much larger crystallites.

Dimension of the holotype: Diameter is $18.5 \mu \mathrm{m}$; width of archaeopyle is $5.5 \mu \mathrm{m}$; Plate 2, Figures $1,4,7$; SEM photograph nos. 51968-51973, film-no. 1484/21-26; SEM stub no. I-47.

Type-locality and stratum typicum: DSDP Leg 41, Hole 366A, Core 4, Section 4, 64 to $66 \mathrm{~cm}$; late Pliocene (Discoaster brouweri Zone, NN 18).

Derivatio nominis: granifer (Latin) = bearing grains; for composition of the test ultrastructure of numerous minute grains.

Age and range of species: $T$. granifera is present, abundant to rare, in sediments from the Sierra Leone Rise ranging in age from late Pliocene to Pleistocene (Discoaster pentaradiatus Zone, NN17 to
Emiliania huxlei Zone, NN 21). The latest occurrence of $T$. granifera was observed from just below the Holocene/Pleistocene boundary in cores from the eastern North Atlantic.

\section{Thoracosphaera tesserula n. sp.}

(Plate 3, Figures 1-8, 10, 11)

Description from SEM examinations: The test is quite spherical and 23 to $29 \mu \mathrm{m}$ in diameter. The archaeopyle is circular in outline and 8 to $12 \mu \mathrm{m}$ in width. An operculum has not been observed.

The ultrastructure of the test wall is composed of randomly orientated crystallites of flat prismatic shape, 0.5 to $2 \mu \mathrm{m}$ in length, 0.8 to $2 \mu \mathrm{m}$ high, and about $0.5 \mu \mathrm{m}$ thick. Both the long and short axes of each crystallite are oriented parallel to the test surface whereas the intermediate axis is vertical to the surface. This results in a mosaic-like or tesselated pattern.

The long and flat side faces of the crystallites, forming the proximal and distal surface, respectively, are roof-shaped. A pore system is present between the crystallites, similar to that of $T$. tuberosa (Plate 3, Figures 5, 6).

Remarks: Skeletal crystallites of $T$. tesserula are fresh and show smooth crystal faces and a delicate texture without any identifiable overgrowths. Therefore, this species is considered to be very resistant to diagenetic alteration. This makes the distinction between this species and others, such as $T$. saxea or $T$. deflandrei, very simple.

Dimensions of the holotype: Diameter of the test is $25.5 \mu \mathrm{m}$; width of archaeopyle is $12.5 \mu \mathrm{m}$; Plate 3, Figures 1, 4, 7, 10; SEM photograph nos. 51727-51731, film no. 1479/17-21; SEM stub no. I220.

Type-locality and stratum typicum: DSDP Leg 41, Hole 366A, Core 37, core catcher; Oligocene (Globorotalia opima opima Zone).

Derivatio nominis: tesserula $($ Latin) $=$ mosaic stone; for composition of skeletal ultrastructure of crystallites arranged in a mosaic or tesselated pattern.

Age and range of species: In sediments from the Sierra Leone Rise $T$. tesserula is present, rare to very rare, from Paleocene to upper Oligocene (Globorotalia pusilla Zone to Globigerina ciperoensis ciperoensis Zone); for details see Table 3.

\section{Thoracosphaera deflandrei Kamptner, 1956}

(Plate 4, Figures 1-6)

*Thoracosphaera deflandrei n.sp. Kamptner, 1956, Osterreich. Bot. Z., v. 103, fig. 1-3.

Thoracosphaera deflandrei Kamptner. Stradner, 1961, Erdol. Z., v. 77 , p. 84 , fig. 74

Thoracosphaera $\mathrm{cf}$. T. deflandrei. Haq and Lipps, 1971, Deep Sea Drilling Proj., Initial Report, v. 8 , p. 789 , pl. $6=T$. heimi.

Thoracosphaera deflandrei Kamptner. Haq and Lohmann, 1975, Woods Hole Oceanogr. Inst., Tech. Rept. WHOI-75-45, p. 157, p. 157 , pl. 3 , fig. $10=T$. heimi.

Description from SEM examinations: The test is completely spherical and 18 to $29.5 \mu \mathrm{m}$ in diameter. The inarticulate circular archaeopyle is 6.5 to $8 \mu \mathrm{m}$ in width comprising $1 / 3$ of the test diameter. The test consists of one layer 2 to $3 \mu \mathrm{m}$ in thickness. This is equal to the height of the single skeletal crystallites which, on an average, are $1 \mu \mathrm{m}$ in width. These crystallites are radially oriented and tightly packed without any pore-like structure, thus forming a very resistant sphere.

The skeletal ultrastructure is composed of single crystallites representing polygonal prisms whose distal surfaces are irregularly rounded, sometimes having euhedral crystal faces, whereas the proximal terminations show pointed three-sided pyramids.

Remarks: For description and illustration from light microscopy see Kamptner (1956).

This species differs from $T$, heimi mainly by its smaller skeletal elements. The absence of pores or pore-like structures and the presence of a larger test, also allows positive identification.

The characteristics of the ultrastructure of the distal and/or proximal surface are undoubtedly not primary in origin, but result from diagenetic overgrowth. This is indicated by euhedral crystallite surfaces on the proximal side as well as by the coarse and blocky crystallite surfaces of the distal side (Plate 4, Figures 3, 5).

Age and range of species: On the Sierra Leone Rise, $T$. deflandre $i$ is common to moderately common in sediments from early Miocene to middle Miocene age (for details see Table 3 ). 
$T$. deflandrei is reported from the Eocene of Donzacq, France (Kamptner, 1956), from Neocomian to Eocene (Stradner, 1961) and Stradner (1963) gives it a range from Mesozoic to Tertiary.

\section{Thoracosphaera saxea Stradner, 1961}

(Plate 4, Figures 7-12)

Thoracosphaera sp. Bramlette and Riedel, 1954, J. Paleontol., v. 28 , p. 393 , pl. 38 , fig. 5 .

*Thoracosphaera saxea n.sp. Stradner, 1961, Erdoel-Z., v. 77, p. 84, fig. 71 .

Thoracosphaera saxea Stradner. Stradner, 1963, in Gohrbandt, Mitt. Geol. Ges. Wien, v. 56 , p. 78 , pl. 10 , fig. 8 .

Thoracosphaera saxea Stradner. Cohen, 1964, Micropaleontology, v. 10 , p. 248 , pl. 5 , fig. $6 \mathrm{a}-\mathrm{e}$, non pl. 6 , fig. $6=T$. deflandrei.

Thoracosphaera saxea Stradner. Boudreaux and Hay, 1969, Rev. Esp.

Micropal., v. 1 , p. 265 , pl. 4 , fig. 2 , non pl. 4 , fig. $3-5=T$. albatrosiana.

Description from SEM examinations: The test is quite spherical with a diameter of 18.5 to $28 \mu \mathrm{m}$ with a maximum from 22 to $24 \mu \mathrm{m}$. The circular archaeopyle is 6 to $9 \mu \mathrm{m}$ in diameter with the operculum only occasionally attached.

The test wall is formed by one layer of about 1.5 to $2 \mu \mathrm{m}$ thickness composed of single, irregularly formed, partly roundish in distal view, but in most cases curved to elongated, slim crystallites which are wedge shaped and tightly packed to produce a very solid sphere.

The texture of the distal surface, characterized by elongated curved or partly vermiculate crystallites, is comparable to a parquet pattern. The texture of the proximal surface differs by showing more compact and often euhedral crystallites. Pore Structures are not visible at all.

Remarks: See Stradner (1961) for a description and illustration of this species from light microscopy. $T$. saxea differs from $T$. deflandre $i$ only by size and shape of skeletal crystallites. In the former they are wedge-shaped and more elongated whereas in the latter these crystallites are smaller and irregularly rounded.

Parallel striations and/or smooth outlines of crystallites of the distal surface and euhedral crystal faces on proximal surfaces indicate that the original crystallite ultrastructure has been altered by diagenetic overgrowth.

Age and range of species: On the Sierra Leone Rise, T. saxea is common in sediments from the Paleocene to the early Miocene; for details see Table 2.

T. saxea is reported from the Danian (Stradner, 1961), from the Paleocene (Stradner, 1963), from the Late Cretaceous of Austria and the Tertiary as well as from Holocene marine sediments (Cohen, 1964) and from late Pliocene to Holocene of the Nicaragua Rise (Boudreaux and Hay, 1969).

\section{Thoracosphaera albatrosiana Kamptner, 1963}

(Plate 5, Figures 1-12)

*Thoracosphaera albatrosiana n. sp. Kamptner, 1963, Ann. Naturhistor. Mus. Wien, v. 66 , p. 177, fig. 30 .

Thoracosphaera deflandrei Kamptner. Stradner, 1963, in Gohrbandt, Mitt. Geol. Ges. Wien, v. 56, pl. 10, fig. 9-10.

Thoracosphaera albatrosiana Kamptner. Kamptner, 1967, Ann. Naturhistor. Mus. Wien, v. 71 , p. 154, fig. 78-80.

Thoracosphaera ricoseta n.sp. Kamptner, 1967, Ann. Naturhistor. Mus. Wien, v. 71 , p. 159 , fig. 87.

Thoracosphaera saxea Stradner. Boudreaux and Hay, 1969, Rev. Esp. Micropal., v. 1, pl. 4, fig. 3-5.

Thoracosphaera albatrosiana Kamptner. Fütterer, 1976, N. Jb. Geol. Paleont. Abh., v. 151, fig. 7-12.

Description from SEM examinations: The test is quite spherical with a diameter of 18 to $32 \mu \mathrm{m}$. The large apical archaeopyle comprises about $2 / 3$ of the test diameter, sometimes showing rudiments of a reflected tabulation which, by connection with the archaeopyle suture, indicates a tabulation pattern of $1 \mathrm{a}-3 \mathrm{a}$ and $2^{\prime}-4^{\prime}$ of the operculum.

The skeletal ultrastructure is composed of crystallites 1.6 to 2.4 $\mu \mathrm{m}$ long and 0.3 to $0.6 \mu \mathrm{m}$ wide. They display smooth proximal bases and pointed, three-sided, pyramid-like distal surfaces showing plain crystal faces. Actually, 12 to 18 crystallites are arranged in a circular pattern with a central pore of 0.5 to $1 \mu \mathrm{m}$ in diameter. This produces a striking reticulate pattern on the test wall.

Remarks: Extensive descriptions and excellent illustrations from light microscopy are given by Kamptner $(1963,1967)$.
$T$. albatrosiana is very resistant to diagenetic alterations, both crystallite overgrowth and dissolution. Specimens as old as Miocene show no alteration of their ultrastructure, although other nannoplankton and foraminifers in the same sample show strong recrystallization.

T. albatrosiana can be easily be confused in some cases with Calciodinellum operosum. Both species show identical skeletal ultrastructure in all details and only insignificant differences in test size. The only characteristic of $C$. operosum is crystallite ridges which reflect its tabulation. If these ridges become highly reduced, then difficulties in recognition arise.

An additional form occurs with $T$. albatrosiana s.str., which is identical with it in size, shape of the test, and in fundamental skeletal architecture. A single but striking difference is seen in skeletal ultrastructure. The skeletal crystallites are considerably smaller, 0.1 to $0.4 \mu \mathrm{m}$ wide, and show only blurred crystal faces which results in a granular texture. Because the latter has the same pore width as $T$. albatrosiana s.str., a much larger number of crystallites forms the ring-like pattern.

All observations on $T$. albatrosiana s.str. show this species to be very resistant to visible diagenetic alterations. This suggests that the "granular" form is not derived from $T$. albatrosiana s.str. by diagenetic crystallite overgrowth.

It should be remarked, however, that some specimens of the "granular" type exhibit larger crystallites with plain crystal faces below their granular crystallites (Plate 5, Figure 6). On the other hand, this "granular" type is always present in the same Pleistocene samples in which $T$. heimi is present and shows no alteration in all details, although it is most susceptible to diagenetic alteration.

A further detail leading to rejection of the diagenetic interpretation is the fact that both types, $T$. albatrosiana s.str., as well as the "granular" type, without exception occur jointly in the same samples. Furthermore, one would expect to find speciments showing mixed texture of both types, but this is never the case.

In rejecting a diagenetic origin of these ultrastructural differences, the question arises as to whether the "granular" type might be a proper species on its own. Until now there have not been enough observations regarding the variability of skeletal crystallites within calcareous dinoflagellates to use such modifications for systematic purposes. $C$. operosum is undoubtedly closely related to $T$. albatrosiana s.str. and shows a striking variability of the height of the crystallite ridges bodering the plate areas (Futterer, 1976).

The ultrastructure of the skeletal elements of $T$. heimi also exhibits large differences in construction, size, and pattern (Figure 3). For these reasons the above-mentioned "granular" type is included in $T$. albatrosiana s.str. to avoid an unnecessary splitting of this species.

Age and range of species: On the Sierra Leone Rise, $T$. albatrosiana is present and common to abundant from the early Miocene to the Pleistocene. Maximum frequency has been observed in the late Pleistocene.

\section{Thoracosphaera tuberosa Kamptner, 1963}

(Plate 6, Figures 1-10)

*Thoracosphaera tuberosa n.sp. Kamptner, 1963, Ann. Naturhistor. Mus. Wien, v. 66, p. 179, fig. 26.

Thoracosphaera narena n.sp. Kamptner, 1967, Ann. Naturhistor. Mus. Wien, v. 71, S. 158, fig. 96-99, 101, 103.

Thoracosphaera candora n.sp. Kamptner, 1967, Ann. Naturhistor. Mus. Wien, v. 71, p. 157, fig. 100, 102, 105, 106.

Thoracosphaera tuberosa Kamptner. Futterer, 1976, N. Jb. Geol. Palaont. Abh., v. 151, fig. 13-18.

Description from SEM examinations: The spherical test is 22 to 32 $\mu \mathrm{m}$ in diameter and shows a large archaeopyle which comprises about two-thirds of the test diameter and has an irregular serrated margin.

The skeletal ultrastructure is composed of numerous interconnected crystallites, 1.8 to $2.5 \mu \mathrm{m}$ high and 1-2.5 $\mu \mathrm{m}$ wide, showing three-sided, pointed pyramids with plain crystal faces and well-defined edges on their distal surfaces. The proximal surface is formed by plain crystallite bases of polygonal outline.

Pore openings are seen on the lower areas of the pyramid faces. These pores do not go directly through the test but pass in a complicated way partly inside the crystallites and partly between them (Plate 6, Figure 10).

Remarks: For description and illustrations from light microscopy examinations see Kamptner $(1963,1967=T$. candora and $T$. narena $)$. 
Skeletal crystallites of this species seem to be relatively resistant to diagenetic alteration. Apart from a slight granulation on distal crystallite faces (Plate 6, Figure 6), no alterations could be observed.

A "diagenetic connection" to $T$. deflandrei which might be possible because of the basic dimensions and architecture of its skeletal crystallites is rejected because of different archaeopyle construction.

Age and range of species: On the Sierra Leone Rise, $T$. tuberosa is present and rare to moderately frequent from the late Pliocene to the Pleistocene. Highest abundance is reached in the youngest samples; for details see Table 3 .

In the literature this species is reported from the middle Pleistocene of the Pacific (Kamptner, 1963) and from the Pliocene to the Present in the southeast North Atlantic (Futterer, 1976).

Thoracosphaera sp.

(Plate 8, Figures 1, 2, 4, 5)

Remarks: The test shows the dimensions, width, and outline of the archaeopyle and the skeletal ultrastructure of $T$. albatrosiana. Numerous projections or spines which are spread in large numbers all over the test are a unique but striking difference. The spines are especially situated on the joints of the reticulated test structure and vary from 1 to $2 \mu \mathrm{m}$ in length. The weakly expanded proximal part is smooth and $0.5 \mu \mathrm{m}$ in diameter. The capitate distal termination is in the form of a $1-\mu \mathrm{m}$ thick rhombohedron-like crystallite.

In their natural habit these spines are grouped very regularly and can hardly be regarded as secondary crystallite overgrowth. Moreover, there are specimens which support spines only in a very incomplete way.

Similarly, the longer projections or spines are found in the modern Peridinium trochoideum (Wall et al., 1970). There is variability in cyst spination, which may be dense and complete, but is often only rudimentarily developed.

The principle similarity of $T$. sp. 1 with $T$. albatrosiana is important. On the other hand, spine formation on the cyst is certainly a fundamental specific criterion, thus these specimens could not be grouped with $T$. albatrosiana. Because of the small number of specimens already found, the formulation of a new species will not be attempted here.

Age and range of species: On the Sierra Leone Rise, $T$. sp. 1 is present and rare to very rare in the uppermost Miocene and the Pliocene; for details see Table 3.

Thoracosphaera sp. 2

(Plate 7, Figures 1-7)

Remarks: The test is spherical and 20 to $25 \mu \mathrm{m}$ in diameter. The test wall is about $2 \mu \mathrm{m}$ in thickness. Single crystallites are composed of minute granular elements of 0.1 to $0.2 \mu \mathrm{m}$ which are stacked to rod-shaped crystallites about $2 \mu \mathrm{m}$ long. These crystallites are tightly packed in a radial palisade-like way, producing a massive and solid test.

The proximal terminations of the crystallites are plain while the distal part terminates in a pointed, three-sided pyramid which sometimes may become coarser by secondary crystallite overgrowth showing a dense patchy or mosaic pattern.

Until now, width and outline of the archaeopyle could not be determined definitively. Present observations, however, indicate that this species possesses a large, apical archaeopyle whose diameter is about two-thirds that of the test diameter. In its outlines the archaeopyle seems to show the remains of a reflected tabulation of the type indicated for $T$. tuberosa or $T$. albatrosiana.

This species has been described in open nomenclature, until a definite evaluation of the size and outline of the archaeopyle has been made. Certain similarities in size of the test and in the skeletal ultrastructure are to be seen in comparison with $T$. granifera, which possesses a small, circular archaeopyle.

Age and range of species: On the Sierra Leone Rise, $T$. sp. 2 is present only very rarely and has been found until now only in two samples from the middle Miocene and the late Miocene. Other than this, it has been found in the Pliocene of Site 369 on the continental slope off the Spanish Sahara.

\section{Thoracosphaera sp. 3}

(Plate 8, Figures 3, 6)

Remarks: The test of this species is quite spherical and $25 \mu \mathrm{m}$ in diameter. It possesses a very large circular archaeopyle which is nearly the same as the test diameter. It is closed by an unsegmented operculum with a plain rim.

The skeletal crystallites are unusually coarse and robust. On the distal surface they look like three-sided pyramids with large, plain crystal faces. The crystallite ultrastructure of the proximal side is not quite clear but on the whole it is more complicated (Plate 8, Figure 6). Orientation of the skeletal crystallites is normally rather irregular, but the equatorial zone seems to be more ordered and shows a neckletlike pattern (Plate 8, Figure 3).

In the crystallite shape, but not in size, there are similarities to $T$. tuberosa or $T$. sp. 5. Both differ significantly in archaeopyle construction. Thoracosphaera sp. 4 differs from this species by having irregularly formed crystallites with rudimentary spines.

Age and range of species: On the Sierra Leone Rise, this species is present only very rarely. Up to now only one specimen from the Pleistocene (Emiliania huxlei Zone, NN 21) has been found.

Thoracosphaera sp. 4

(Plate 8, Figures 7, 8, 10, 11)

Remarks: The test is spherical and about $22 \mu \mathrm{m}$ in diameter. The archaeopyle is very large, circular, plain rimmed, and normally closed by an unsegmented operculum.

The skeletal ultrastructure is composed of relatively large crystallites of irregular outline showing the rudimentary onsets of spines. There seems to be no special orientation of elemental crystallites (Plate 8, Figures 10,11), but an overall orientation of inequatorially running lines is clearly visible (Plate 8 , Figures 7,8 ).

In the skeletal ultrastructure, especially in the outline of the crystallites, but also in the width and outline of archaeopyle, there are evident similarities to the cysts of Peridinium trochoideum, which differ from Thoracosphaera sp. 4 only by having well-developed spines and less-ordered crystallite arrangement.

Age and range of species: On the Sierra Leone Rise, this species is present only very rarely and has been found in only two samples of Pleistocene age; for details see Table 3 .

\section{Thoracosphaera sp. 5}

(Plate 8, Figures 9, 12)

Remarks: The test of this species is quite spherical and about 20 to $25 \mu \mathrm{m}$ in diameter. The circular, slightly serrated archaeopyle is 7 to $10 \mu \mathrm{m}$ in width, which is about one-third that of the test diameter. An operculum has not been observed until now.

The skeletal ultrastructure is composed of randomly oriented small crystallites, which on their distal surface show three-sided pointed pyramids with plain crystal faces. This is a remarkable feature. Even in samples showing very strong diagenetic alterations, extreme overgrowth on discoasters or dissolution and recrystallization of foraminifers, skeletal crystallites ot $T$. sp. 5 are fresh delicate, and without any signs of diagenetic influence.

The skeletal ultrastructure of this species is nearly identical to $T$. tuberosa. Differences between these species are smaller skeletal crystallites, smaller test diameter and, most significantly, a smaller, circular archaeopyle in $T$. sp. 5 .

Age and range of species: On the Sierra Leone Rise, $T$. sp. 5 is present and rare to very rare from the Paleocene to the late Oligocene; for details see Table 3 .

\section{Thoracosphaera sp. 6 \\ (Plate 3, Figures 9, 12)}

Remarks: This is the largest species observed until now; it is quite spherical and 35 to $40 \mu \mathrm{m}$ in diameter. Because of the few specimens examined, outline and width of the archaeopyle could not be determined precisely. However, it appears that a circular archaeopyle of intermediate size is present.

Skeletal crystallites are very similar to those ot $T$. albatrosiana but less regularly arranged in a reticulate pattern. Open pores are recognizable in only a few cases.

Though a close relationship to T. albatrosiana is clearly apparent, more observations are needed to decide the question if differences in skeletal ultrastructure might be a result of diagenesis. Existing observations on T. albatrosiana, however, show an extreme resistance to the diagenetic alteration of its ultrastructure.

Age and range of species: On the Sierra Leone Rise, T. sp. 6 is represented by only a few specimes in Sample 366A-39, CC, from the Oligocene. 


\section{Genus CALCIODINELLUM Deflandre, 1947}

Calciodinellum operosum Deflandre, 1947

(Plate 6, Figures 11-13; Plate 7, Figures 7-12)

*Calciodinellum operosum n. sp. Deflandre, 1947, C.R. Acad. Sci. Paris, v. 224, p. 1781-1782, fig. 1-6.

Calciodinellum operosum Deflandre. Deflandre, 1948, Botaniste, v. 34 , p. $202-204$, fig. 1-9.

Calciodinellum operosum Deflandre. Wall and Dale, 1968, J. Paleontol., v. 42, p. 1403, test-fig. 2, 10-13, pl. 172, fig. 9-12.

Thoracosphaera sp. Edwards, 1973, Deep Sea Drilling Proj., Initial Report, v. 21, pl. 3, fig. 2-3.

Calciodinellum operosum Deflandre. Fütterer, 1976, N. Jb. Geol. Paläont. Abh., 151, p. 135-136, fig. 1-6.

Description from SEM examinations: The test of this species is quite spherical, showing perfectly reflected tabulation of $4^{\prime}, 3 \mathrm{a}, 7^{\prime \prime}$, $6 \mathrm{c}, 5^{\prime \prime \prime}, 2^{\prime \prime \prime \prime}$ and 2 s.p., which normally agrees in all details with the description by Wall and Dale (1968). The tabulation is caused by crystallite ridges of different height which reach a maximum of $4 \mu \mathrm{m}$ along this dimension. The large archaeopyle (about two-thirds of the test diameter) is formed by detachment of an operculum comprising plate-areas $2^{\prime}-4^{\prime}$ and 1a-3a. The observation of Wall and Dale (1968) that parts of plate-area $2 \mathrm{a}$ remain with the epitract is confirmed. Some operculi, however, show an additional plate area lying between $2^{\prime}, 4^{\prime}$, and $3^{\prime}$ (Plate 6, Figure 12), which perhaps could be referred to plate-area 1' which is displaced posteriorly and occluded from direct contact with plate area $3 \mathrm{a}$.

The overall diameter of the specimens examined is between 20 and $45 \mu \mathrm{m}$. Variations depend mainly on the great variety in height of crystallite ridges bordering the plate areas. Thickness of the test wall is 1.5 to $2.5 \mu \mathrm{m}$.

The skeletal ultrastructure is composed of small crystallites, 1.5 to $2.5 \mu \mathrm{m}$ in height and 0.3 to $0.6 \mu \mathrm{m}$ in thickness. Crystallites show a smooth base (equal to the inner test surface) and a pointed, threesided, pyramid-like distal surface with plain crystal faces. Twelve to 18 crystallites are interconnected and arranged to irregular rings forming a reticulate test pattern with central pores of 0.2 to $1 \mu \mathrm{m}$ in diameter.

The crystallite ridges bordering the plate-areas are formed by single lines of crystallites normally starting their growth from the proximal surface (Plate 7, Figures 10,11). But this remains a point of discussion because specimens showing very low ridges have ridgeforming crystallites that appear to be seated on the normal crystallites of the test.

Remarks: For description and illustrations of $C$. operosum from light microscopy see Deflandre $(1947,1948)$ and Wall and Dale (1968).

The ultrasculpture of this well-tabulated species shows in dimension, appearance, and orientation of its skeletal crystallites complete correspondence with the nontabulated $T$. albatrosiana (see Fütterer, 1976). Difficulties in determination may arise in cases where the crystallite ridges bordering the plate-areas become highly reduced.

Age and range of species: On the Sierra Leone Rise, $C$. operosum is present and rare to abundant from the early Miocene to the Pleistocene. Some doubtful occurrences are of Oligocene age; for details see Table 3 .

In the literature this species is reported from the Miocene (Sahélien = stratum typicum, Deflandre, 1947), from the Pleistocene sediment cores of the Caribbean Sea (Wall and Dale, 1968), from the southwest Pacific (Edwards, 1973), from modern sediments of the southeast North Atlantic, and from the Persian Gulf (Futterer, 1976).

Subfamily PERIDINOIDEAE (provisional, Wall and Dale)

\section{Genus PERIDINIUM Ehrenberg}

Peridinium cf. Peridinium trochoideum (Stein) Lemmermann (Plate 9, Figures 1-8)

Remarks: Spinose, calcareous dinoflagellate cysts have been described hitherto only from Peridinium trochoideum (Wall and Dale, 1968; Wall et al., 1970). Within this species the spines are quite variable in size and the number distributed on the test wall (Wall et al., 1970).

The present specimens closely resemble each other, and those described as $P$. trochoideum, in principal construction of the test.
Greater differences are shown only in spine distribution and development. Therefore, all specimens examined here are provisionally classed with $P$. trochoideum.

The test is generally spherical to weakly ovid and 22 to $30 \mu \mathrm{m}$ in diameter. The test is composed of 2 to $4 \mu \mathrm{m}$ wide and about $1 \mu \mathrm{m}$ thick, polygonal, platelet-like skeletal elements each supporting one projection or spine jutting from its center. The bases of the skeletal platelets, in general, show up to six pore-like perforations which are not fixed in their relative positions, but often are found on the edges of the skeletal elements. The spines are slender rods with pointed, acuminate or capitate terminations. They are 1 to $7 \mu \mathrm{m}$ in length (whereas Wall et al., 1970), mention 1 to $12 \mu \mathrm{m}$ ) and are circular to three-sided in cross-section.

Rhabdosphaera erinaceus and $R$. nigra have a spherical form and a longish-ovid form, of $32 \mu \mathrm{m}$ or $25 \mu \mathrm{m}$ in diameter, respectively. They have been described and pictured by Kamptner (1940) from water samples off the Istrian coast. These forms belong to the group of calcareous dinoflagellates. Treating $R$. erinaceus with hydrochloric acid reveals an inner acid-insoluble membrane, just as described from $P$. trochoideum by Wall et al. (1970). A general relationship of $R$. erinaceus and $R$. nigra with the genus Thoracosphaera has already been mentioned by Kamptner (1955). Later these species were grouped as Rhabdothorax erinaceus and Rhabdothorax nigra within the subfamily Thoracosphaeroideae (Kamptner, 1958).

Age and range of species: On the Sierra Leone Rise, Peridinium cf. $P$. trochoideum is present from the late Miocene to the Pleistocene in many samples but always in small numbers.

An adequate specimen has been described by Hekel (1973) as Thoracosphaera sp. from the Eocene of the Ita Mai Tai Seamount (Pacific). Specimens described by Wall and Dale (1968) and Wall et al. (1970) were obtained from modern sediments or from fresh clonal cultures.

\section{ACKNOWLEDGMENTS}

The author would like to thank U. Pflaumann and E. Seibold for providing samples and extensive shipboard data as well as for numerous helpful discussions. The writer wishes to thank C. Samtleben for excellent cooperation and substantial discussions. Technical help by A. Dohrmann, B. Hecht, W. Reimann, and U. Schuldt is acknowledged.

Finally, the author acknowledges financial support by the Deutsche Forschungsgemeinschaft.

\section{REFERENCES}

Adelseck, C.G., Geehan, G.W., and Roth, P.H., 1973. Experimental evidence for the selective dissolution and overgrowth of calcareous nannofossils during diagenesis: Am. Geol. Soc. Bull., v. 84, p. 2755-2762.

Berger, W.H., 1968. Planktonic foraminifera: selective solution and paleoclimatic interpretation: Deep-Sea Res., v. 15 , p. $31-43$.

Boudreaux, J.E. and Hay, W.W., 1969. Calcareous nannoplankton and biostratigraph' of the late PliocenePleistocene-Recent sediments in the Submarex cores: Rev. Esp. Micropal., v. 1, p. 249-292.

Bramlette, M.N. and Martini, E., 1964. The great change in calcareous nannoplankton fossils between the Maestrichtian and Danian: Micropaleontology, v. 10, p. 291-322.

Bramlette, M.N. and Riedel, W.R., 1954. Stratigraphic value of discoasters and some other microfossils related to recent coccolithophores: J. Paleontol., v. 28, p. 385-403.

Cohen, C.L.D., 1964. Coccolithophorids from two Caribbean deep-sea cores: Micropaleontology, v. 10, p. 231-250.

1965. Coccoliths and discoasters from Adriatic bottom sediments: Leid. Geol. Meded., v. 35, p. 1-44.

Deflandre, G., 1947. Calciodinellum nov. gen., premier représentant d'une famille nouvelle de Dinoflagellés fossiles à théce calcaire: C. R. Acad. Sci. Paris, v. 224, p. 1781-1782. 
1948. Les Calciodinellidés dinoflagellés fossiles à théce calcaire: Botaniste, v. 34, p. 191-219.

Edwards, A.R., 1973. Calcareous nannofossils from the southwest Pacific, Deep Sea Drilling Project, Leg 21. In Burns, R.E., Andrews, J.E., et al., Initial Reports of the Deep Sea Drilling Project, Volume 21: Washington (U.S. Government Printing Office), p. 641-691.

Fütterer, D., 1976. Kalkige Dinoflagellaten ("Calciodinelloideae") und die systematische Stellung der Thoracosphaeroideae: N. Jb. Geol. Paleontol. Abh., v. 151 , p. 119-141.

Haq, U.Z.B. and Lipps, J.H., 1971. Calcareous nannoplankton. In Tracy, J.I., Jr., et al. 1971, Initial Reports of the Deep Sea Drilling Project, Volume 8: Washington (U.S. Government Printing Office), p. 777-789.

Haq, B.U. and Lohmann, G.P., 1975. Early Cenozoic calcareous nannoplankton biogeography of the Atlantic Ocean: Woods Hole Oceanographic Inst., Tech. Rept., WHOI-75-45, p. 157.

Hekel, K., 1973. Nannofossil biostratigraphy, Leg 20, Deep Sea Drilling Project. In Heezen, B.C., MacGregor, I.E., et al., Initial Reports of the Deep Sea Drilling Project, Volume 20: Washington (U.S. Government Printing Office), p. 221-247.

Kamptner, E., 1927. Beitrag zur Kenntnis adriatischer Coccolithophoriden: Arch. Protistenk., v. 58, p. 173-184. 1928. Uber das System und die Phylogenie der Kalkflagellaten: Arch. Protistenk., v. 64, p. 19-43. , 1940. Die Coccolithineen der Südwestküste von Istrien: Ann. Naturhistor. Mus. Wien, v. 51, p. 54-149. 1944. Coccolithineen-Studien im Golf von Neapel: Wien Bot. Z., v. 93, p. 138-147. 1946. Zur Kenntnis der Coccolithineen-Gattung Thoracosphaera Kpt: Anz. Akad. Wiss. Wien Mathematische-naturwissenschaftliche Klasse, v. 83 , p. 100103.

1954. Untersuchungen über den Feinbau der Coccolithen: Arch. Protistenk., v. 100, p. 1-90.

1955. Fossile Coccolithineen-Skelettreste aus Insulinde: Verh. K. Ned. Akad. Wet. Afd. Nat., R. 2 Deel L, No. 2, p. 106.

1956. Thoracosphaera Deflandrei nov. spec., ein bemerkenswertes Kalkflagellaten Gehäuse aus dem Eocän von Donzacq (Dep. Landes, Frankreich): Wien. Ost. Bot. Z., v. 103 , p. $448-456$.

, 1958. Betrachtungen zur Systematik der Kalkflagellaten, nebst Versuch einer neuen Gruppierung der Chrysomonadales: Arch. Protistenk., v. 103, p. 54-116.
1963. Coccolithineen-Skelettreste aus Tiefseeablagerungen des Pazifischen Ozeans: Ann. Naturhistor. Mus. Wien, v. 66, p. 139-204.

1967. Kalkflagellaten-Skelettreste aus dem Tiefseeschlamm des Südatlantischen Ozeans: Ann. Naturhistor. Mus. Wien, v. 71, p. 117-198.

Lohmann, H., 1920. Die Bevölkerung des Ozeans mit Plankton nach den Ergebnissen der Zentrifugenfänge während der Ausreise der "Deutschland" 1911, zugleich ein Beitrag zur Biologie des Atlantischen Ozeans: Arch. Biont., v. 4, p. 1-617.

McIntyre, A. and McIntyre, R., 1971. Coccolith concentrations and differential solution in oceanic sediments. In Funnell, B.M. and Riedel, W.R. (Eds.), The micropaleontology of oceans: Cambridge (Cambridge University Press), p. 253-261.

Müller, C., 1974. Calcareous nannoplankton, Leg 25 (Western Indian Ocean). In Simpson, E.S.W., Schlich, R., et al, Initial Reports of the Deep Sea Drilling Project, Volume 25: Washington (U.S. Government Printing Office), p. 579-633.

Perch-Nielsen, L., 1971. Durchsicht tertiärer Coccolithen. In Farinacci, A. (Ed.), 2nd Plankt. Conf. Proc. Rome, 1970: Roma (Edizioni Tecnoscienza), v. 2, p. 939-980.

Reinhardt, P., 1972. Coccolithen.-Kalkiges Plankton seit Jahrmillionen: Die Neue Brehm Bücherei, Wittenberg Lutherstadt (A. Ziemsen Verlag), p. 99.

Stradner, H., 1961. Vorkommen von Nannofossilien im Mesozoikum und Alttertiär: Erdol-Z., v. 77, p. 77-88. 1963. In Gohrbandt, K.: Zur Gliederung des Paläogen im Helvetikum nördlich Salzburg nach planktischen Foraminiferen: Mitt. Geol. Ges, Wien, v. 56, p. 1117.

Wall, D. and Dale, B., 1966. "Living fossils" in western Atlantic plankton: Nature, v. 211, p. 1025-1026.

1967. The resting cysts of modern marine dinoflagellates and their paleontological significance: Rev. Paleobot. Palynol., v. 2, p. 349-354.

1968. Quarternary calcareous dinoflagellates (Calciodinellideae) and their natural affinities: J. Paleontol., v. 42, p. 1395-1408.

Wall, D., Dale, B., and Harada, K., 1973. Description of new fossil dinoflagellates from the late Quaternary of the Black Sea: Micropaleontology, v. 19, p. 18-31.

Wall, D., Guillard, R.R.L., Dale, B., and Swift, E., 1970. Calcitic resting cysts in Peridinium trochoideum (Stein) Lemmermann, an autotrophic marine dinoflagellate: Phycologia, v. 9, p. 151-156. 


\section{PLATE 1}

Scanning electron photomicrographs showing different stages of preservation of Thoracosphaera heimi (Lohmann)

Kamptner, 1920; gun potential $10 \mathrm{kv}$; scale bar $=5 \mu \mathrm{m}$.

Figure 1 Oblique apical view of an unaltered specimen without any dissolution or overgrowth (3000×, 51933; Sample 366A-1-1, 71-73 cm).

Figures 2, 5

2. Overall view of an unusually large specimen $(2000 \times, 51920)$.

5. Detail of outer surface of same specimen without overgrowth; note irregular construction of elemental crystallites and somewhat irregular distribution of pores $(6000 \times, 51918$; Sample $366 \mathrm{~A}-1-1,71-73 \mathrm{~cm})$.

Figures 3, 6

3. Overall view of specimen showing beginning dissolution and overgrowth (3000X, 48389).

6. Detail of outer surface of same specimen showing dissolution by parallel striation on single elements and accretion by filling the pores. Contours of elemental crystallites are still visible $(6000 \times, 48388$; Sample 366A-9, $\mathrm{CC})$.

Figure 4 Apical view of a very small specimen of the type represented by squares in Figure 3; elemental crystallites are fused to platelets; remnants of pores are clearly visible by weak depressions (3000×, 48395; Sample 366A-9,CC).

The very strongly diagenetically altered specimens of Figures 7-12 are in the literature usually grouped to the proper species

Thoracosphaera imperforata Kamptner, which is invalid.

Figure 7 Cross-section of specimen strongly altered by secondary accretion of calcite; primary delicate platelets are altered to thick and firm elements which are distally and proximally weakly domed (5000×, 49942; Sample 366A-17, CC).

Figures $8,11 \quad 8$. Overall view of specimen showing very heavy secondary overgrowth $(3000 \times, 49551)$.

11. Detail of outer surface of same specimen; elemental crystallites are no longer visible; outlines of elements are smoothed and less irregular; primary pores are still recognizable by weak molds on some elements $(6000 \times$, 49550; Sample 366A-14, CC).

Figures 9, 12 9. Oblique apical view of very heavy altered specimen $(3000 \times, 49515)$.

12. Detail of outer surface of same specimen; outlines of elements are extremely smoothed and primary pores are only recognizable in exceptional cases $(6000 \times, 49514$; Sample $366 \mathrm{~A}-13, \mathrm{CC})$.

Figure 10 Detail of inner surface of an extremely strong altered specimen showing elements with euhedral crystal faces $(6000 \times, 50509$; Sample 366A-22, CC). 


\section{PLATE 1}
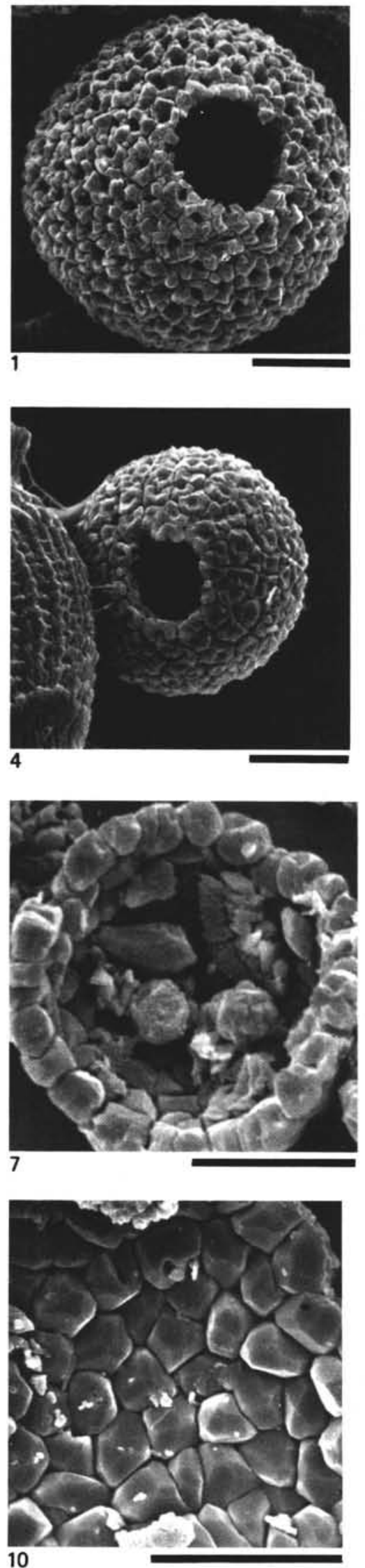
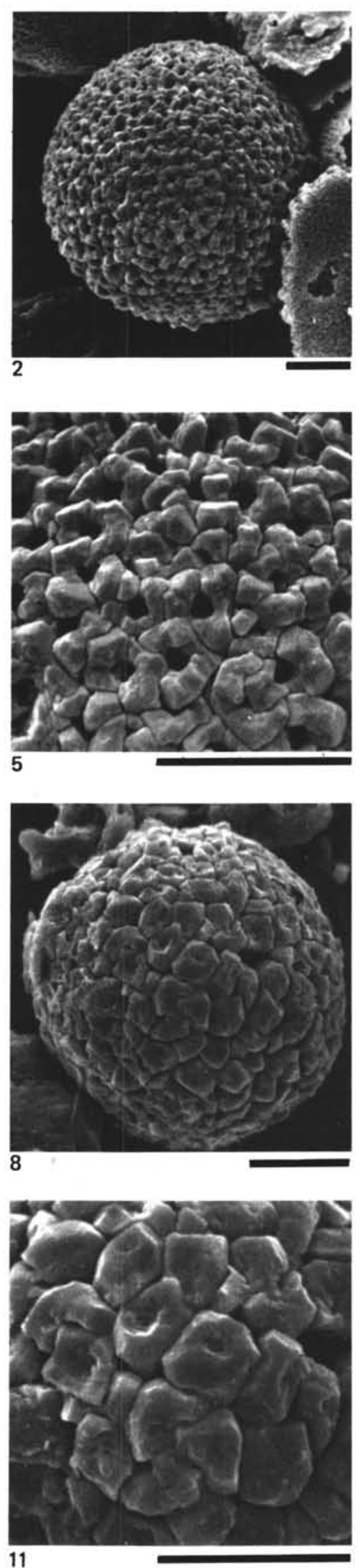
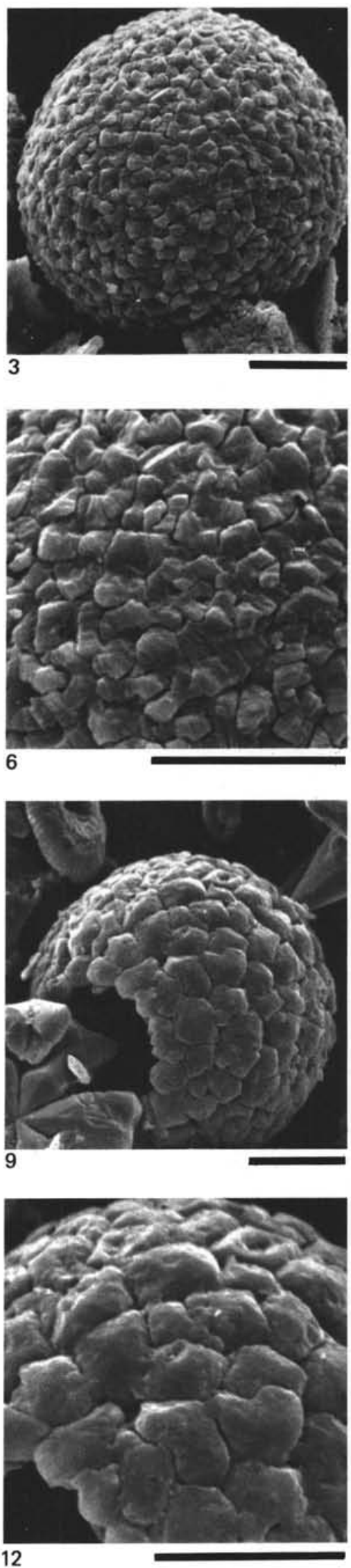


\section{PLATE 2}

Thoracosphaera granifera n.sp.; scanning electron photomicrographs; gun potential $10 \mathrm{kv}$; scale bar $=5 \mu \mathrm{m}$

Figures 1,4,7 1. Overall view of holotype (2000X, 51970).

4. Oblique apical view of holotype showing the overall arrangement of the minute granular crystallites $(3000 \times, 51971)$.

7. Detail of outer surface of holotype $(6000 \times$, 51968; Sample 366A-4-4, 64-66 cm.

Figures $2,5,8$ 2. Oblique apical view of paratype (2000X, 47398).

5. Detail of outer surface of same specimen; note the pore-like habit of the test because of the abnormal loose packing of the minute granular crystallites (6000X, 45397).

8. Detail of archaeopyle of same specimen (6000×, 47399; Sample 366A-3-4, 68-70.

Figures $3,6 \quad 3$. Overall view of paratype, archaeopyle not to be seen $(2000 \times, 47757)$.

6. Detail of outer surface of same specimen with tightly packed crystallites $(6000 \times, 47756$; Sample 366A-4, CC).

Figure 9 Oblique apical view of paratype with attached operculum (2000×, 49143; Sample 366A-4-5, 32$34 \mathrm{~cm})$.

Figure 10 Cross-section of test wall showing the ultrastructure composed of numerous minute granular crystallites (6000×, 47089; Sample 366A-4-4, 64$66 \mathrm{~cm})$

Figure 11 Detail of outer surface of a slightly diagenetically altered specimen. The test seems to disintegrate into smaller platelets of irregular outline $(6000 \times$, 51356; Sample 369-2-2, 67-69 cm).

Figure 12 Detail of outer surface of moderately altered specimen showing secondary microgranular overgrowth which masks the primary ultrastructure (6000×, 51329; Sample 369-2-1, 64-66 cm). 
PLATE 2
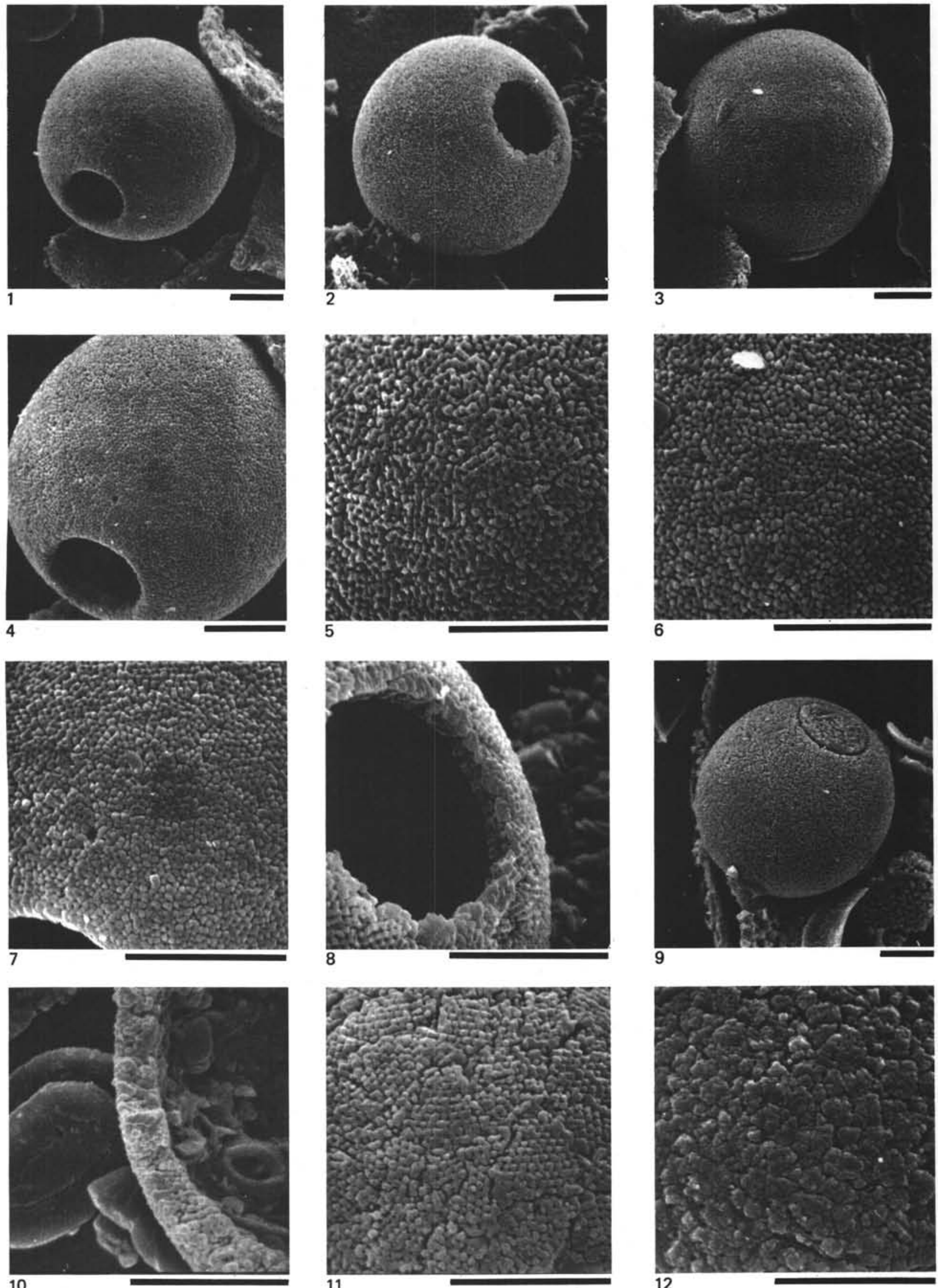


\section{PLATE 3}

Thoracosphaera tesserula n.sp.; scanning electron photomicrographs; gun potential $10 \mathrm{kv}$; scale bar $=75 \mu \mathrm{m}$.

Figures 1, 4, 7, 1. Apical view of holotype $\left(2000 \times, 51727,10^{\circ}\right)$. 10

4. Cross-section through test of holotype at the rim of the archaeopyle showing details of skeletal architecture $\left(6000 \times, 51728,10^{\circ}\right)$.

7. Oblique lateral view of holotype $(2000 \times$, $\left.51730,45^{\circ}\right)$.

10. Close up of outer surface of holotype showing details of tesselated test architecture (6000X, $51729,45^{\circ}$; Sample 366A-37, CC).

Figures 2, 5 2. Overall view of paratype (2000X, 51562).

5. Detail of outer surface of same specimen (6000×, 51560; Sample 366A-34, CC).

Figures 3,6 3. Overall view of paratype (2000X, 51542).

6. Detail of outer surface os same specimen showing very compact skeletal crystallites (6000×, 51540; Sample 366A-31, CC).

Figures 8,11 8. Overall view of paratype (2000X, 51570).

11. Detail of outer surface of same specimen (5000×, 51579; Sample 366A-34, CC).

Figures 9, 12 Thoracosphaera sp. 6.

9. Overall view of specimen $(1600 \times, 52221)$.

12. Close-up of outer surface of same specimen showing unusually large crystallites arranged in an irregular partly obscured reticulate pattern $(4000 \times, 52220$; Sample 366A-39, CC). 
PLATE 3
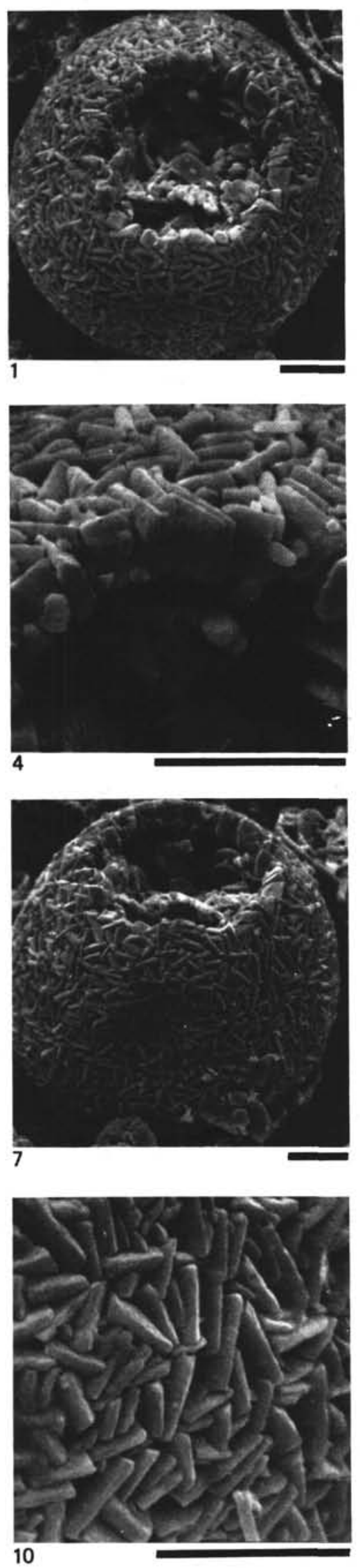
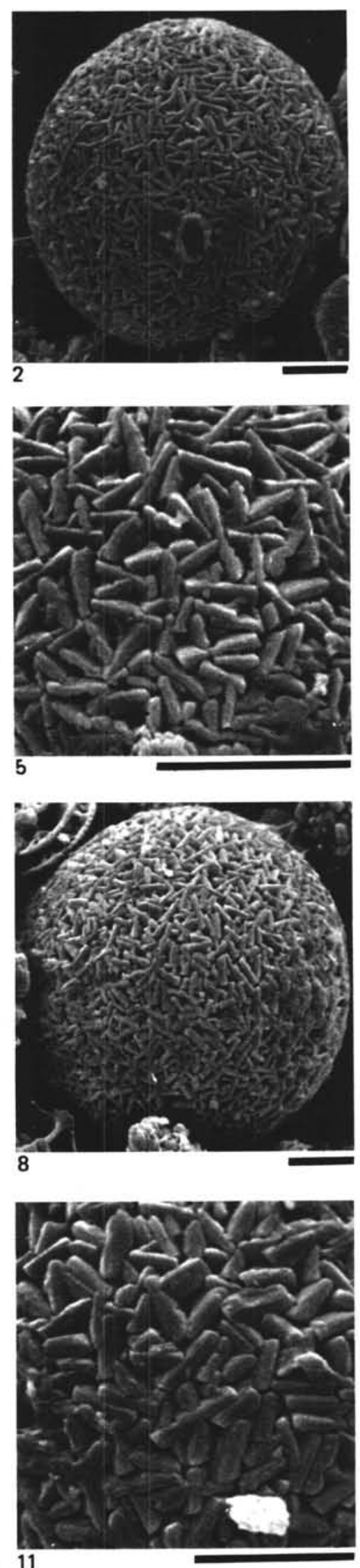
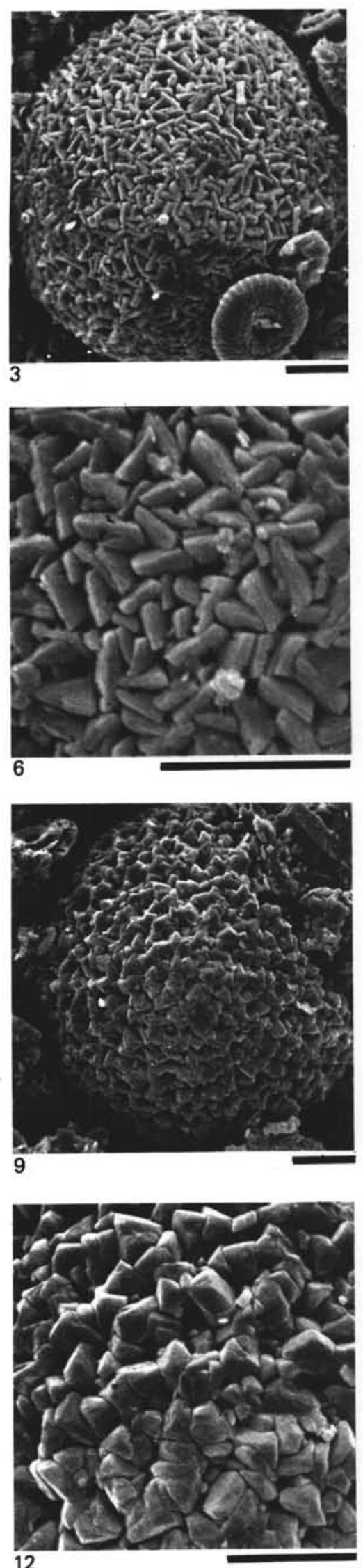


\section{PLATE 4}

Figures 1-6 Thoracosphaera deflandrei Kamptner, 1956; scanning electron photomicrographs; gun potential $10 \mathrm{kv}$; scale bar $=5 \mu \mathrm{m}$.

1. Overall view of specimen, archaeopyle not visible $(2000 \times, 49564)$.

4. Detail of outer surface of same specimen showing unusually small skeletal crystallites (6000×, 49563; Sample 366A-15, CC).

2. Lateral view of specimen showing small apical archaeopyle (2000×, 49952).

5. Detail of outer surface of same specimen showing tightly packed, blunt crystallites with somewhat euhedral outlines $(6000 \times, 49951$; Sample 366A-18, CC.)

3. Detail of inner surface; note the crystallites terminating in pointed three-sided pyramids probably due to diagenetic overgrowth (3000×, 49971; Sample 366A-18, CC).

6. Cross-section of test wall showing details of crystallite ultrastructure; note parallel striation caused by recrystallization $(6000 \times$, 49962, Sample 366A-18, CC).

Figures 7-11 Thoracosphaera saxea Stradner, 1961; scanning electron photomicrographs; gun potential $10 \mathrm{kv}$; scale bar $=5 \mu \mathrm{m}$.

7. Oblique lateral view of complete specimen (2000×, 50225).

10. Detail of outer surface of same specimen showing composition of ultrastructure; note irregular but sharp outline of randomly oriented crystallites $(6000 \times, 50223$; Sample 366A-21, CC).

8. Oblique apical view of complete specimen $\left(2000 \times, 50244,24^{\circ}\right)$.

11. Detail of outer surface of same specimen (6000×, 50245, $0^{\circ}$; Sample 366A-21, CC).

9. Detail of inner surface of broken specimen showing tightly packed crystallites (3000X, 50563; Sample 366A-26, CC).

10. Cross-section of test wall showing details of crystallite arrangement; note keystone-like packing $(6000 \times, 50565$; Sample 366A-26, $\mathrm{CC})$. 
PLATE 4
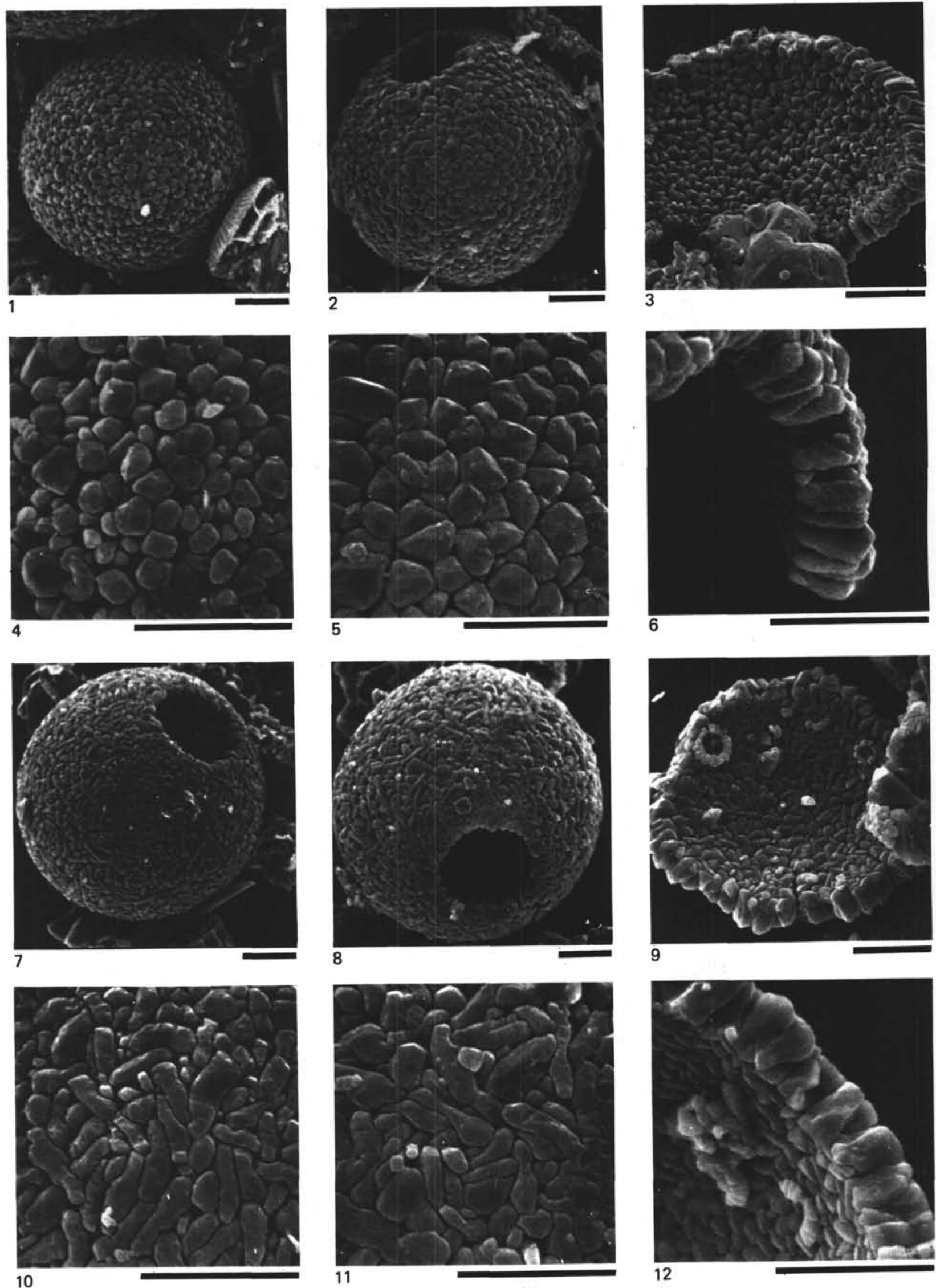


\section{PLATE 5}

Thoracosphaera albatrosiana Kamptner, 1963; scanning electron photomicrographs; gun potential $10 \mathrm{kv}$; scale bar $=5 \mu \mathrm{m}$.

Figures 1, 4

Figures 2, 5

Figures 3, 6

Figures 7, 10

Figure 8

Figures 9,12

Figure 11
1. Complete specimen of typical type with attached operculum in oblique apical view; the archaeopyle suture is marked only in ventral and lateral areas $(2000 \times, 51898)$.

4. Close-up of outer surface of same specimen showing detailed arrangement of crystallites in a reticulate test pattern $(6000 \times, 51897$; Sample 366A-1-1, $71-73 \mathrm{~cm}$ ).

2. Overall view of a complete specimen of typical type $(2000 \times, 51907)$.

5. Close-up of outer surface showing detailed crystallite arrangement $(6000 \times, 51905$; Sample 366A-1-1, 71-73 cm).

3. Oblique apical view of an atypical "granular" specimen with attached operculum (2000X, 51314).

6. Close-up of outer surface of same specimen; note the small granular crystallites forming the reticulate test pattern $(6000 \times, 51313$; Sample 366A-1-4, 43-45 cm).

7. Overall view of an atypic specimen (2000X, 48394).

10. Close-up of outer surface of same specimen; the reticulate pattern is formed by minute pyramid-shaped crystallites and is clearly different from those of Figures 4 or 5 (6000X, 48393; Sample 366A-9, CC).

Cross-section through broken specimen of typical type showing details of crystallite arrangement and proximal surface; note that the crystallites are as long as the test is thick (5000×, 51923; Sample $366 \mathrm{~A}-1-1,71-73 \mathrm{~cm}$ ).

9. Overall view of an atypic "granular" specimen (2000×, 51913).

12. Close-up of outer surface of same specimen; note the small euhedral crystals forming the reticulate test pattern, compare to Figure 6 (6000×, 51910; Sample 366A-1-1, 71-73 cm).

Cross-section through the test wall of an atypic "granular" specimen showing ultrastructure of the test composed by numerous minute euhedral crystals stacked one upon another $(6000 \times, 51929$; Sample 366A-1-1, 71-73 cm). 
PLATE 5
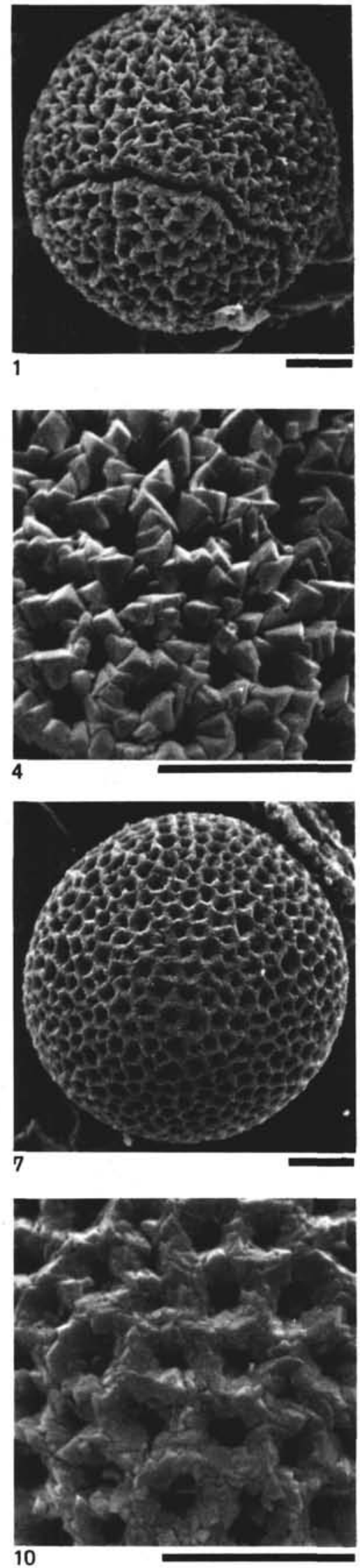
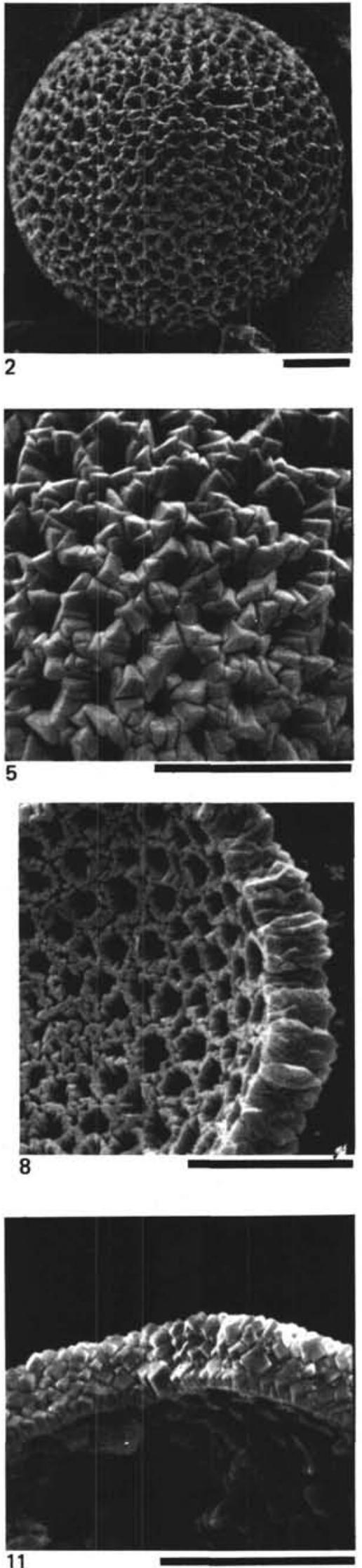
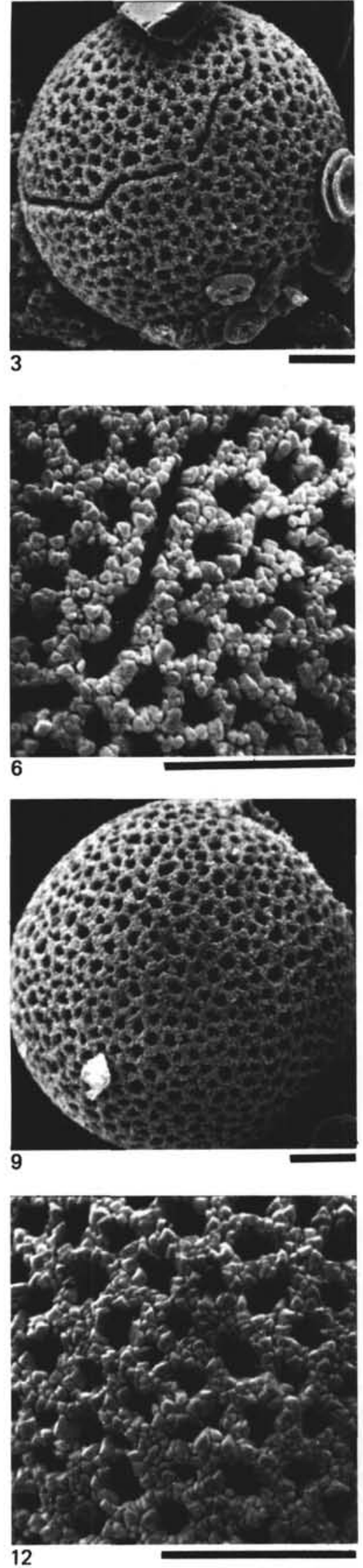


\section{PLATE 6}

Figures 1-10 Thoracosphaera tuberosa Kamptner, 1963; scanning electron photomicrographs; gun potential $10 \mathrm{kv}$; scale bar $=5 \mu \mathrm{m}$.

1. Overall view of a rather small specimen; archaeopyle sutur slightly visible (left) (2000×, 51941).

4. Close-up of outer surface of same specimen showing proximal openings of pore-like structures between the crystallites (6000X, 51939; Sample 366A-1-1, 71-73 cm).

2. Overall view of a complete specimen (2000X, 51904).

5. Close-up of outer surface of same specimen showing details of well-preserved crystallites (6000X, 51902; Sample 366A-1-1, 71-73 cm).

3. Overall view of complete specimen with rather small crystallites (2000X, 47428).

6. Close-up of outer surface of same specimen showing slight overgrowth on crystal faces (6000X, 47427; Sample 366A-3-6, 33-35 cm).

7. Lateral view of specimen with removed operculum; archaeopyle suture is only weakly but distinctly serrated $(2000 \times, 51290$; Sample $366 \mathrm{~A}-1-2,71-73 \mathrm{~cm}$ ).

8. Detail of inner surface of broken specimen showing outlines of skeletal crystallites (3000×, 51899; Sample 366A-1-1, 71-73 cm).

9. Cross-section through test wall showing structure and arrangement of skeletal crystallites $(6000 \times, 47080$; Sample 366A-3, $\mathrm{CC})$.

10. Oblique view on inner surface of broken specimen showing single crystallites, their complex architecture, and lateral interfingering producing pore-like openings between them $(6000 \times, 46768$; Sample 366A-1, CC).

Figures 11-13 Calciodinellum operosum Deflandre, 1947; scanning electron photomicrographs; gun potential $10 \mathrm{kv}$; scale bar $5 \mu \mathrm{m}$.

11. Oblique view on the large apical archaeopyle; ventral $=$ upper left corner $(2000 \times, 48910$; Sample 366A-10, CC).

12. Vertical view on a detached, isolated operculum showing perfect tabulation (3000×, 51302; Sample 366A-1-4, 43-45 cm).

13. Complete specimen in lateral view with attached operculum (right) and perfect tabulation by fairly narrow crystallite ridges $(2000 \times$, 41770; Sample 366A-1, CC). 
PLATE 6
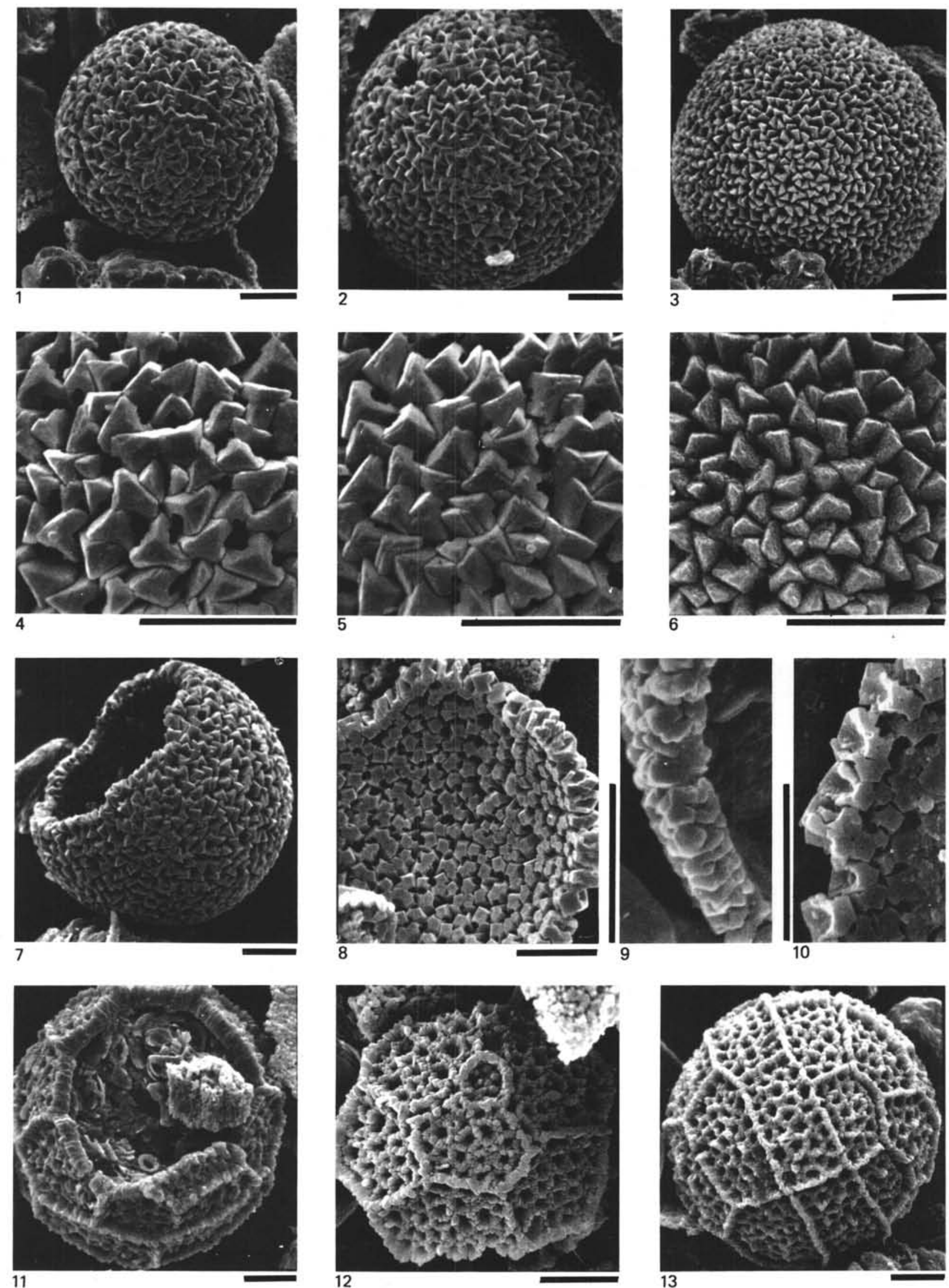


\section{PLATE 7}

Thoracosphaera sp. 2; scanning electron photomicrographs; gun potential $10 \mathrm{kv}$; scale bar $=5 \mu \mathrm{m}$

Figures 1,4 1. Oblique apical view of complete specimen with large archaeopyle (2000×, 48939).

4. Close-up of test wall of same specimen showing skeletal ultrastructure composed of tightly packed stalked crystallites (6000X, 48940; Sample 366A-10, CC).

Figures 2, 3,5 2. Lateral view of a partly broken specimen; size and outline of archaeopyle is not determinable by certainty $\left(2000 \times, 51347,60^{\circ}\right)$.

3. Close-up of outer surface of same specimen showing tightly packed rhombohedronshaped crystallites $\left(6000 \times, 51346,60^{\circ}\right)$.

5. Cross-section through test wall of same specimen showing ultrastructure composed of tightly packed, stalked crystallites terminating in rhombohedron crystallites probably as an effect of diagenetic overgrowth (6000X, $51345,10^{\circ}$; Sample 369-2-2, 67-69 cm).

Figure 6 Close-up of outer surface of partly broken specimen showing crystallites terminating in minute pointed pyramids $(6000 \times, 49578$; Sample $366 \mathrm{~A}-15, \mathrm{CC})$.

Calciodinellum operosum Deflandre, 1947; scanning electron photomicrographs; gun potential $10 \mathrm{kv}$; scale bar $=5 \mu \mathrm{m}$.

Figure 7 Apical view of specimen showing large archaeopyle and complete reflected tabulation by high ridges composed of slender crystallites (2000X, 48044; Sample 366A-1-3, 71-73 cm).

Figure 8 Oblique dorsal view of specimen showing incomplete tabulation in the sulcal area (1200X, 48067; Sample 366A-2-5, 68-70 cm).

Figures 9,12 9. Two specimens in overall lateral (left) and antapical view (right) $(1000 \times, 47438)$.

12. Close-up of outer surface of larger specimen of Figure 9; note that skeletal ultrastructure apart from crystallite ridges of reflected tabulation is identically to that of $T$. albatrosiana $(6000 \times, 47439$; Sample 366A-3-6, 33-35 cm).

Figures 10,11 10. Overall view of broken specimen showing inner surface and cross-section through test wall $\left(2000 \times, 47443,10^{\circ}\right)$.

11. Close-up of cross-section of test wall, same specimen; at least some crystallites of the ridges start their growth from the inner surface while others seem to be put on the crystallites of the outer test surface $(6000 \times$, 47441, 20; Sample 366A-3-6, 33-35 cm). 
PLATE 7
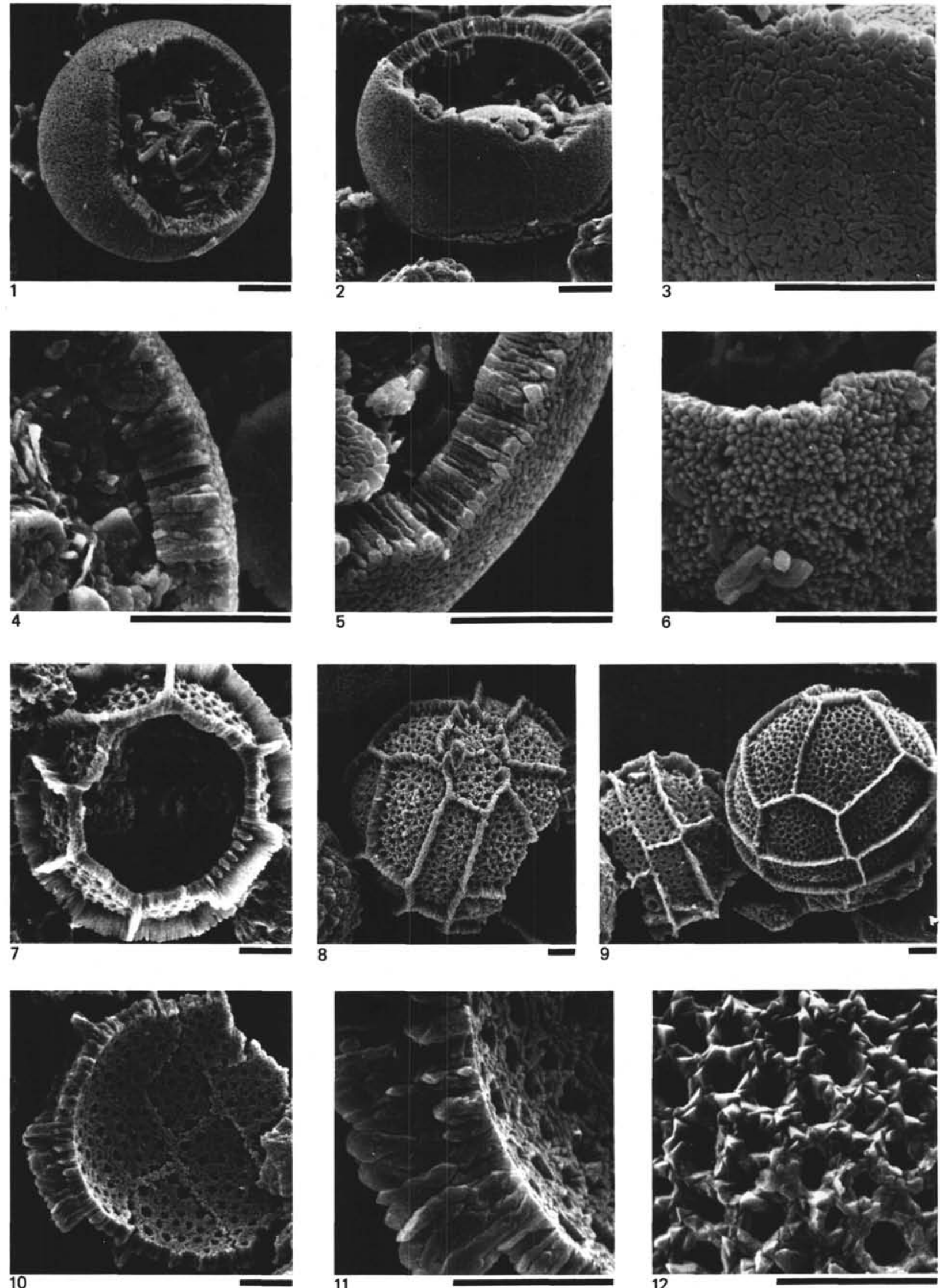


\section{PLATE 8}

Thoracosphaerids in open nomenclature; scanning electron photomicrographs; gun potential $10 \mathrm{kv}$; scale bar $=5 \mu \mathrm{m}$.

Figures 1, 2, 4, Thoracosphaera sp. 1.

5

1. Oblique apical view of a complete specimen showing a large archaeopyle which in its outlines marks remains of a reflected tabulation $\left(2000 \times, 49154,40^{\circ}\right)$.

2. Close-up of archaeopyle rim of same specimen showing oblique view of rhombohedron terminated spines $\left(6000 \times, 49150,10^{\circ}\right.$ rotated).

4. Cross-section through test wall showing details of skeletal ultrastructure $(6000 \times$, 48914; Sample 366A-10, CC).

5. Close-up of same specimen showing vertical view of rhombohedron terminated spines and reticulate test pattern $\left(5000 \times, 49148,10^{\circ}\right.$; Sample 366A-4-5, 32-34 cm).

Figures 3,6 Thoracosphaera sp. 3 .

3. Overall view of specimen with operculum just being detached; note regular arrangement of skeletal crystallites in the equatorial area $\left(2000 \times, 51943,10^{\circ}\right)$.

6. Close-up of outer surface of same specimen showing ultrastructure of crystallites at the archaeopyle rim $\left(6000 \times, 51946,70^{\circ}\right.$; Sample $366 \mathrm{~A}-1-1,71-73 \mathrm{~cm})$.

Figures 7, 8, Thoracosphaera sp. 4.

10,11 7. Overall view of specimen with attached operculum $(2000 \times, 51938)$.

10. Close-up of outer surface of same specimen showing irregular outlines of skeletal crystallites and rudimentary development of spines $(6000 \times, 51937$; Sample 366A-1-1, 71-73 $\mathrm{cm})$.

8. Overall view of complete specimen $(2000 \times$, 46829).

11. Close-up of outer surface of same specimen showing small projections or rudimentary spines on each crystallite $(6000 \times, 46827$; Sample 366A-2, CC).

Figures 9, 12 Thoracosphaera sp. 5.

9. Overall view of complete specimen showing a probably small, circular archaeopyle (2000×, 51722).

12. Close-up of outer surface of same specimen; note fresh appearance of crystallite faces and lacking of any secondary overgrowth (6000X, 51721; Sample 366A-37, CC). 
PLATE 8
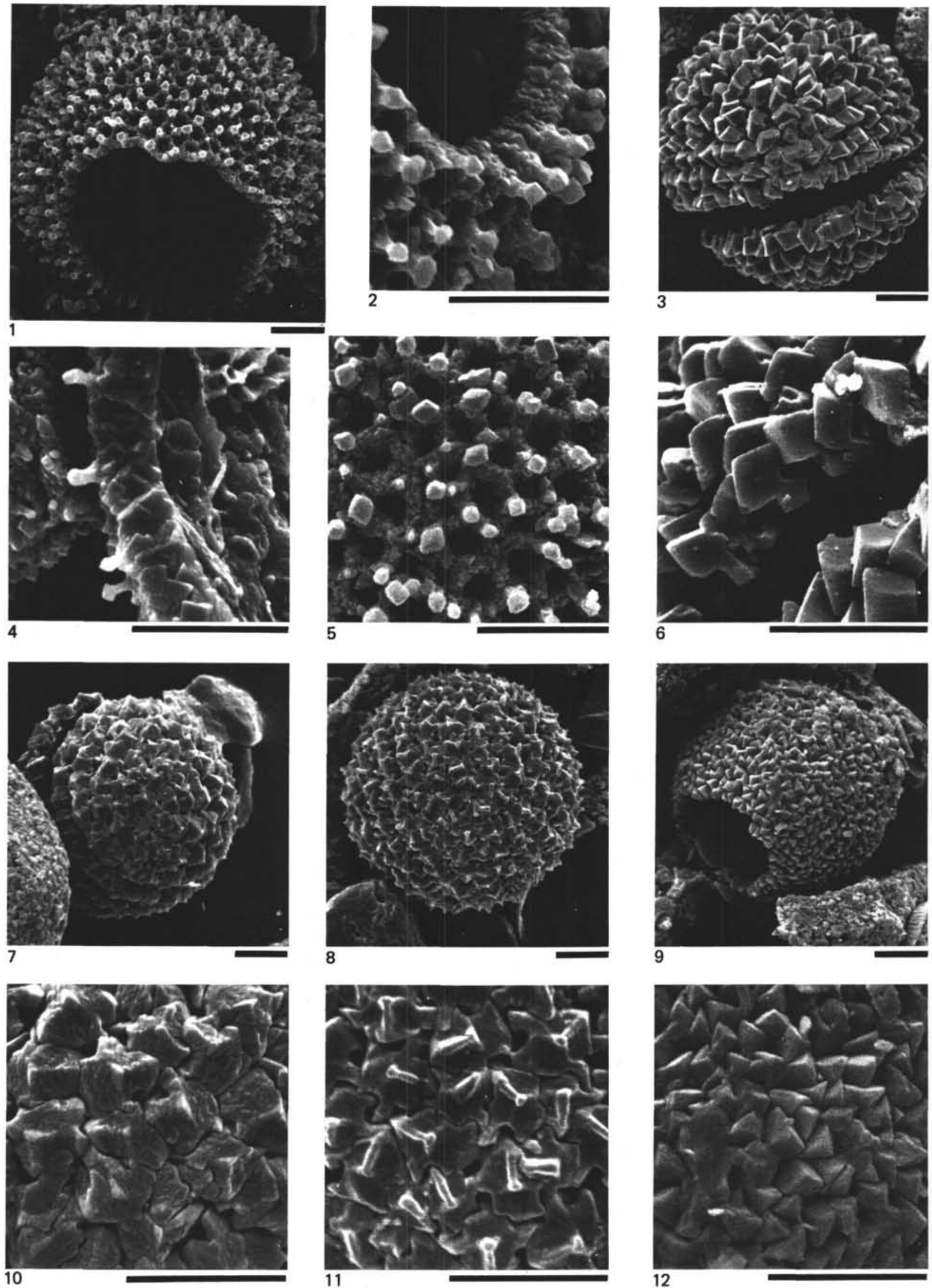


\section{PLATE 9}

Peridinium cf. Peridinium trochoideum (Stein) Lemmermann; scanning electron photomicrographs; gun potential $10 \mathrm{kv}$; scale bar $=5 \mu \mathrm{m}$.

Figures 1,3 1. Overall view of specimen showing regular spines with pointed terminations $(2000 \times$, 51311).

3. Close-up of outer surface of same specimen showing irregular outlines of interfingering crystallites; pointed spines are deltoid in crosssection $(6000 \times, 51309$; Sample 366A-1-4, 43-45 $\mathrm{cm})$.

Figures 2, 5 2. Apical view of specimen with large archaeopyle showing capitate terminations $(2000 \times, 47417)$.

5. Close-up of archaeopyle rim of same specimen showing details of spines and their weakly expanded bases in cross-section (3000 $\times, 47419$; Sample 366A-3-4, 68-70 cm).

Figure 4 Overall view of specimen showing numerous primary malformed and broken spines $(2000 \times$, 47066; Sample 366A-3, CC).

Figure 6 Close-up of inner surface of broken specimen showing irregular outlines of interfingering skeletal crystallites $(6000 \times, 49162$; Sample 366 A$3-2,68-70 \mathrm{~cm})$.

Figure 7 Cross-section of archaeopyle rim showing malformed spines with pointed terminations $(6000 \times$, 47072; Sample 366A-3, CC).

Figure $8 \quad$ Oblique view of tubby specimen with large apical archaeopyle and small malformed spines (2000X, 47457; Sample 366A-2-2, 68-70 cm). 
PLATE 9
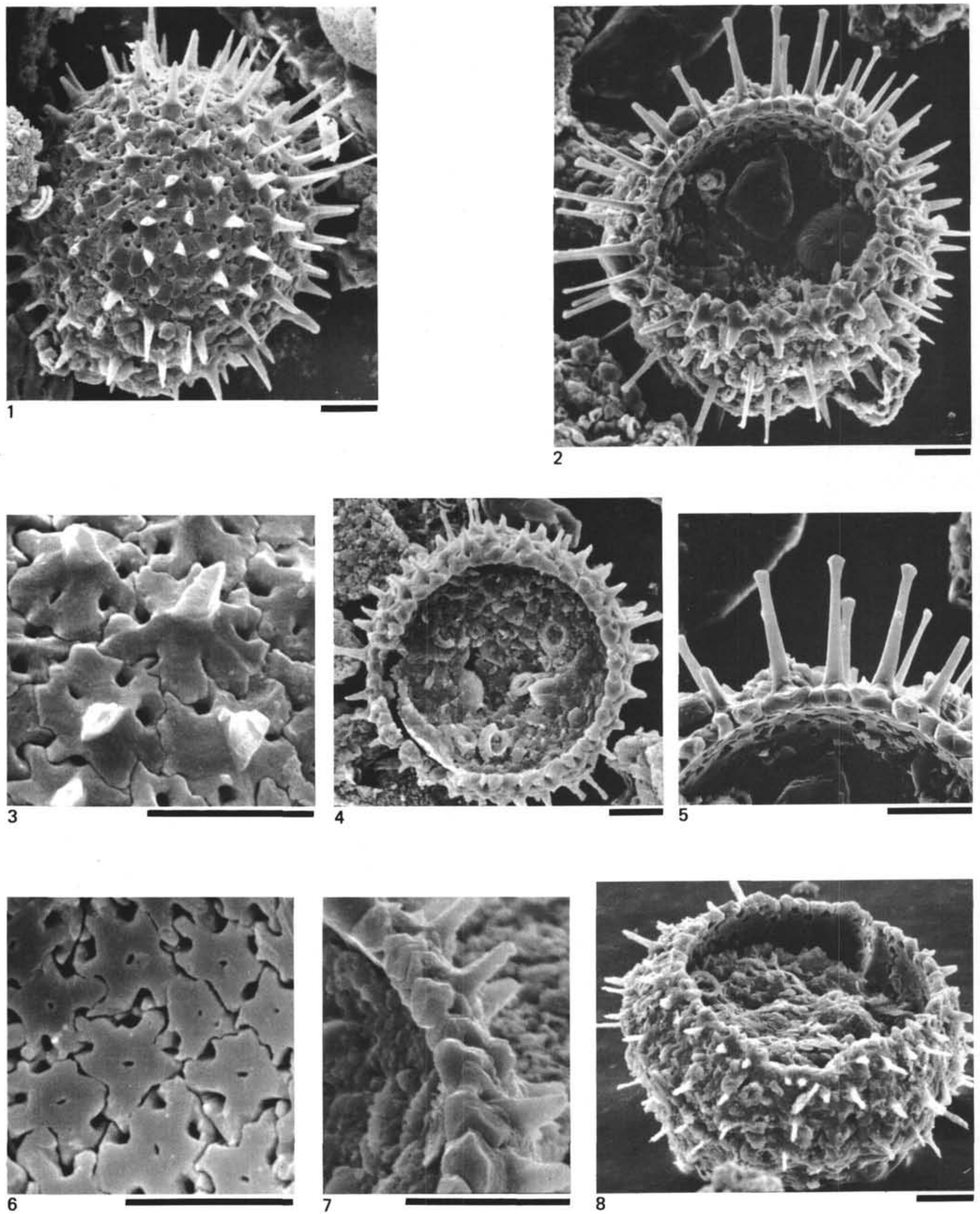